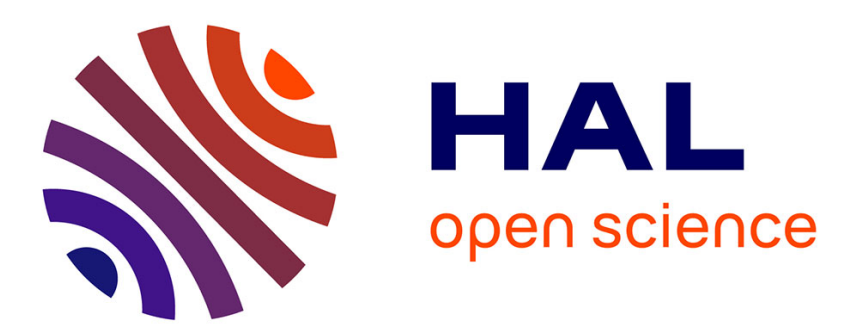

\title{
The Benefits of Intrastate and Interstate Geographic Diversification in Banking
}

Céline Meslier-Crouzille, Donald P. Morgan, Katherine Samolyk, Amine Tarazi

\section{To cite this version:}

Céline Meslier-Crouzille, Donald P. Morgan, Katherine Samolyk, Amine Tarazi. The Benefits of Intrastate and Interstate Geographic Diversification in Banking. 2014. hal-00950504

\section{HAL Id: hal-00950504 \\ https: / hal-unilim.archives-ouvertes.fr/hal-00950504}

Preprint submitted on 21 Feb 2014

HAL is a multi-disciplinary open access archive for the deposit and dissemination of scientific research documents, whether they are published or not. The documents may come from teaching and research institutions in France or abroad, or from public or private research centers.
L'archive ouverte pluridisciplinaire HAL, est destinée au dépôt et à la diffusion de documents scientifiques de niveau recherche, publiés ou non, émanant des établissements d'enseignement et de recherche français ou étrangers, des laboratoires publics ou privés. 


\title{
The Benefits of Intrastate and Interstate Geographic Diversification in Banking
}

This version: February 21, 2014

\author{
Céline Meslier, ${ }^{\mathrm{a},}$, Donald P. Morgan ${ }^{\mathrm{b}}$, Katherine $\operatorname{Samolyk}^{\mathrm{c}}$, Amine Tarazi $^{\mathrm{a}}$ \\ ${ }^{a}$ Université de Limoges, LAPE, 5 rue Félix Eboué, 87031 Limoges Cedex, France \\ ${ }^{b}$ Federal Reserve Bank of New-York, 33 Liberty Street, New York, NY 10045 USA \\ ${ }^{c}$ Consumer Financial Protection Bureau, 1700 G Street, NW, Washington, DC 2055, USA
}

The authors' views do not necessarily reflect those of their employers

\begin{abstract}
We estimate the benefits of intrastate and interstate geographic diversification for bank risk and return, and assess whether such benefits could be shaped by differences in bank size and disparities in economic conditions within states or across U.S. states. For small banks, only intrastate diversification is beneficial in terms of risk-adjusted returns but for very large institutions both intrastate and intrastate expansions are rewarding. However, in all cases the relationship is hump-shaped for both intrastate and interstate diversification indicating limits for banks of all size. Moreover, while our results indicate that the average 'very large' bank has already reached its optimal diversification level, the average 'small bank' could still benefit in terms of risk-adjusted returns from further geographic diversification. Higher economic disparity as measured by the dispersion in unemployment rates either across counties or states impacts the benefits of diversification. At initially low levels of diversification, moving to other markets with dissimilar economic conditions lowers the added value of diversification but it becomes more beneficial at higher diversification levels.
\end{abstract}

JEL Classification: G21, G28

Keywords: Bank Holding Company; Geographic Diversification; Intrastate and interstate disparities in economic activity; Bank risk and return

*Corresponding author: celine.meslier@unilim.fr (Céline Meslier), Tel: + 33555149214. Don.Morgan@ny.frb.org (Donald P. Morgan) katherine.Samolyk@cfpb.gov (Katherine Samolyk), tarazi@unilim.fr (Amine Tarazi). 


\section{Introduction}

U.S. banks are not just becoming larger but also wider. The largest bank holding companies (BHCs) now operate across many states and many more banking markets within states. Similarly, smaller local banks are present in a larger number of counties than in the past. Compared to the vast literature on growing bank size or scale, the widening of U.S. banks and the potential diversification it provides has received relatively little attention. We document trends in geographic diversification for U.S. banks, and investigate how such diversification relates to bank risk and return. We contrast the effects of increasing scope-geographic diversification - with increasing size, or scale and account for potential diversification benefits due to dissimilarities in economic conditions.

Scale and scope refer to two very different but nevertheless interrelated dimensions. When banks get larger by merging with another bank in the same geographic location or some other location with nearly coincident fluctuations in economic activity, such an increase in scale is expected to lower average costs and may provide diversification across products. However, it will not provide any benefits incurred by geographic diversification. Indeed, geographic diversification benefits are associated to new investment opportunities in locations with different economic environments and non-synchronized fluctuations in economic activity. Geographically focused banks are much more exposed to changes in local economic conditions even when they hold a more diversified loan portfolio across a larger number of local consumers. Thus, scale is about spreading the costs of producing assets over fixed factors of production while geographic diversification is about spreading assets over locations with different patterns of returns.

To look into geographic diversification, banks can be considered as a portfolio of loans and improved opportunities to diversify as an upward shift in the risk-return tradeoff facing a banker. However, an improvement in the risk-return tradeoff will not necessarily lead to lower risk; depending on their preferences, some bankers may respond to the improved returns to risktaking by increasing risk, albeit with even greater returns. Whether overall risk goes up or down after diversification increases depends, in the end, on a bank's appetite for risk. But whatever the actual portfolio choice along the improved risk-return tradeoff, risk-adjusted returns (i.e., returns per unit of risk) should be higher at more diversified banks. We therefore investigate the implications of geographic diversification in terms of risk and return but also more specifically in 
terms of risk-adjusted return. We measure bank geographic diversification using the FDIC's annual Summary of Deposits, wherein banks report the amount of deposits at each and every branch in the U.S.. We calculate diversification measures for each banking firm across different markets, where "markets" are defined variously as states, at one extreme, to individual MSAs (Metropolitan Statistical Areas) and rural counties, at the other. Using a sample of 6532 banks with data from 1994 to 2008, i.e. starting when diversification was allowed by the Interstate Banking Act of 1994 (Riegle-Neal) until the important changes driven by the 2008 global financial crisis ${ }^{1}$, we estimate the relationship between geographic diversification, on the one hand, and risk, returns, risk-adjusted returns and default risk, on the other. Existing work considers the effects of geographic diversification either on the market value of listed BHCs (Deng and Elyasini, 2008, Goetz et al., 2013), i.e. large institutions or focuses on small banks located in one state (Goetz, 2012) or small community banks (Emmons et al., 2004). By considering the broadest possible sample of banks, our aim is to investigate the potential benefits of diversification at various size levels and multiple geographic dimensions encompassing the case of a small bank initially operating in a single county or MSA and reaching for new business only a few miles away to the largest institutions spreading across states and internationally. In contrast to micro papers that focus on distance between headquarter and branches (Deng and Elyasini, 2008) or analyze the dynamics of either intrastate branching deregulation (Goetz, 2012) or interstate bank deregulation (Goetz et al., 2013), our aim is to account for heterogeneity in economic conditions within states at the county level and across states nationwide. Specifically, we assess how disparities in economic conditions and business cycles within or across states impact the risk-return outcomes of geographic expansion.

Our results show that for small banks, only intrastate diversification is beneficial in terms of risk-adjusted returns but that for very large institutions both intrastate and interstate expansions are rewarding. However, in all cases the relationship is hump-shaped for both intrastate and interstate diversification indicating limits for banks of all size. Moreover, while our results indicate that the average 'very large' bank has already reached its optimal diversification level, the average 'small' bank could still benefit from further geographic diversification but only

\footnotetext{
${ }^{1}$ While we control for the years 2007 and 2008 in our estimations, we also run all our regressions by excluding observations from 2007 and 2008 and obtain similar findings. Major changes took place later on and therefore we start our investigation in 1994 to capture the diversification trends following the Interstate Banking Act of 1994 and do not go beyond the global financial crisis which is still a transitory period.
} 
if it expands far beyond its local market. Higher economic disparity as measured by the dispersion in unemployment rates either across counties or states impacts the benefits of diversification. At initially low levels of diversification, moving to other markets with dissimilar economic conditions lowers the added value of diversification, but it becomes more beneficial at higher diversification levels.

The remainder of the paper is organized as follows. Section 2 relates our work to previous literature and discusses our research focus. Section 3 presents the data and section 4 our empirical model and results. Section 5 concludes.

\section{Related literature and research focus}

In our study we focus on the U.S., where there has been a distinct shift toward more interstate mergers after 1994. Such a shift followed the Riegle-Neal Interstate Banking and Branching Efficiency Act that enabled banks to acquire banks in another state without that state's permission. In general, the laws that limited banks' geographic reach have gradually eased over the last decades. Starting in the 1970s, individual states began letting banks branch across their own state, and groups of states, or compacts, allowed interstate bank mergers among the states in the compact. In 1982, BHCs were allowed (by the Garn-St. Germain Act) to buy failed banks in any state, regardless of state laws. Before 1994, virtually all mergers involved two banks in the same state, often a healthy bank buying a failing one. The Interstate Banking Act of 1994 (Riegle-Neal) enables BHCs to buy any bank - healthy or not-in any state. Intrastate mergers and bank failures both trailed off in 1994, when interstate mergers accelerated. Both sorts of mergers make banks larger, of course, but interstate mergers tend to make them wider as well. ${ }^{2}$ The number of U.S. commercial banks has sharply declined since the mid 1980's from 14496 banks in 1984 to 7088 banks in $2008^{3}$, and the assets of the average bank more than tripled from $\$ 372$ million in 1984 to 2 billion in 2008. This increase in bank size and the potential returns to

\footnotetext{
${ }^{2}$ Our aim in this paper is not to study mergers. Mergers refer to how banks get bigger or wider. We are interested in what happens (to risk and returns) as banks grow.

${ }^{3}$ Data are available from the website of the FDIC, Historical Statistics on Banking (HSOB): http://www2.fdic.gov/hsob/index.asp.
} 
scale is one of the most studied aspects of bank consolidation. ${ }^{4}$ Until recently, researchers agreed that bank returns are a hump-shaped function of assets and that economies of scale turn into diseconomies before assets reach the multi-billion dollar range. Peristiani (1997) estimates the profit-maximizing level of assets (efficient scale) to be between $\$ 300$ million to $\$ 900$ million. According to these figures the average bank may now be operating above efficient scale. McAllister and McManus (1993) and Wheelock and Wilson (2001) find that banks face increasing returns to scale up to at least $\$ 500$ million of total assets. More recent papers, however, (Feng and Serletis, 2009; Wheelock and Wilson, 2012) find contrasting results. For instance, Wheelock and Wilson (2012) show that most banking organizations, including the largest holding companies, operated under increasing returns to scale over the 1984-2006 period. With their focus on scale, researchers have largely ignored the potential geographic diversification benefits of consolidation in the banking industry. ${ }^{5}$ This disinterest may be partly theory based; investors can hold shares in banks all over the country, so they may not need banks to diversify themselves. Shareholders may even penalize diversification at the firm level if it reduces pressures on managers to perform well. The diversification "discount" for non-financial firms (where the whole firm is worth less than its parts) suggests that investors prefer focused firms with managers that stick to their core business. Laeven and Levine (2007) find a similar diversification discount in the case of the banking industry, indicating that economies of scope are not sufficiently large to produce a diversification premium and to outweigh the costs associated to agency problems. Diversification is however a core business in banking and

\footnotetext{
${ }^{4}$ See Berger, Demsetz, and Strahan (1999) for an overview of the causes and consequences of consolidation. There is also an extensive literature on mergers and potential scale benefits. Rhoades (1994) counted 39 bank mergerefficiency studies between 1980 and 1993 in the U.S. and DeYoung et al. (2009) review 150 studies conducted worldwide after 2000 on bank mergers more generally. In the efficiency studies reviewed by Rhoades, mergers rarely lead to lower average costs, even when the merger is between banks with overlapping markets, where the potential cost savings are the largest. The early studies tend to focus on the potential cost benefits, in part because bank consultants and managers emphasize costs savings. Roughly half of the studies look at market prices, testing whether the price of the merging banks' stock increases near the merger. The other half look directly at the bank's performance, to see if cost performance actually improves following the mergers. Despite the differences in methodology, the results from both types of studies have mostly pointed negative effects; on average, the combined stock prices of the merger banks do not increase following mergers, nor does the cost performance of the merging banks improve. Performance fails to improve even when there is large degree of market overlap, or a large efficiency gap between the acquiring bank and its target. A small number of case studies of mergers suggest reasons why costs may not improve.

${ }^{5}$ Dietsch and Oung (2001) draw a similar conclusion from their study of bank mergers in France: "... market-driven merger strategies based on cost synergies do not seem to be empirically justified. On the other hand, there seems to be an underused potential for income synergies and risk diversification gains."
} 
therefore it seems plausible to expect some upside for banks that are better diversified. Diversification at the bank level may also improve banks' investment decisions if diversification smoothes internal cash flows (via internal capital markets) and helps banks avoid external funding (Houston, James, and Marcus 1997).

While geographic diversification may provide some benefits, spreading across markets is not costless, of course. When opening branches in a new county or a new state, banks face learning costs due to the lack of information on this new market. These costs can be particularly high for banks which specialize in relationship lending such as community banks. As banks geographically expand and therefore become larger, collecting soft information becomes more costly as the distance between the lender and the borrower increases and the transmission of this information across the different management layers becomes more difficult. Moreover, getting wider puts distance between principals (executives and owners) and agents (management) and hence wider banks may face higher agency costs. Costs associated to geographic diversification could hence be different for banks with different business models. As discussed in Stein (2002), lending technologies based on soft information will face decreasing returns to scale but lending technologies relying on hard information can be more easily scaled up. ${ }^{6}$

Though neglected, researchers have not ignored geographic diversification entirely. In their study of listed BHCs, Demsetz and Strahan (1997) find that the largest BHCs were more diversified across census regions, and that such diversification was associated with lower stock return volatility. Assessing the effects of geographic expansion on bank efficiency with a sample of 7000 banks from 1993 to 1998, Berger and DeYoung (2001) find contrasting results. On the one hand, expansion to nearby states or regions tends to positively affect bank efficiency. But, on the other hand, they find that inefficiencies tend to increase with the distance between a bank holding company's headquarters and its subsidiaries, presumably because the managers at a faraway subsidiary have more leeway for mismanagement or shirking. Benefits of geographic expansion are therefore lower when banks move further away, and this effect is stronger for small banks (less than $\$ 100$ million in assets). The negative impact of distance is also reported by Deng and Elyasiani (2008) in terms of higher diversification discount and higher risk. Using a

\footnotetext{
${ }^{6}$ Loutskina and Strahan (2011) highlight changes in the lending behavior of concentrated lenders (banks which operate in one or a few local markets and invest in private information). When they expand beyond their core market, concentrated lenders behave more like diversified lenders (banks which operate in many markets and use public information) in their newly attained markets.
} 
sample of 500 BHC listed banks, the authors analyze the link between geographic diversification and BHC value and risk by focusing on the distance between headquarters and branches. While increased geographic diversification enhances bank value and reduces risk, larger distance generates a diversification discount and higher risk. Hence, the diseconomies associated with distance may limit the gains from geographic diversification. Goetz et al. (2013) also find a negative relationship between geographic diversity, following interstate bank deregulation, and BHC value. According to the authors, this result could reflect agency costs; larger diversity makes it more difficult for outside investors to control insiders which allows them to extract larger private benefits from the bank. Nevertheless, by further exploring the potential benefits of technological progress in the banking industry, Berger and DeYoung (2006) highlight how these changes have facilitated the geographic expansion of U.S. banks by reducing distance-related agency costs and by improving the control of parent banks on their subsidiaries. Benefits of geographic diversification could also result from higher competition in local banking markets. As highlighted by Evanoff and Ors (2008), geographic deregulation in the U.S. had a positive effect on bank efficiency. By increasing competition on local markets, entry of new competitors, through mergers and acquisitions, leads incumbent banks, not involved in the process, to reduce their costs and hence improve their cost efficiency. Moreover, bank diversification could also impact the risk-taking behavior of local non-diversified competitors. Indeed, Goetz (2012) highlight that bank diversification tends to increase bank risk-taking but lowers competitors' risktaking.

These papers do not explore the potential benefits of entering new markets with nonsynchronized fluctuations in economic conditions. When banks are geographically focused, they are much more exposed to changes in local economic conditions even when they hold a more diversified loan portfolio across a larger number of local customers. However, although portfolio theory would predict that geographically concentrated banks would be riskier than geographically diversified banks, there is no clear-cut empirical evidence on the vulnerability of U.S. banks' to local economic shocks. Meyer and Yeager (2001) do not find a significant link between bank performance and local economic conditions. Moreover, focusing on community banks located in a single county, Yeager (2004) does not find local economic shocks (which are independent from state or nationwide economic conditions) to systematically impair bank 
performance. If banks are not actually affected by local economic shocks, the potential benefits of geographic diversification, particularly for community banks may be questioned. Using a technique of simulating mergers, Emmons et al. (2004) investigate the ability of small community banks (i.e. with a total assets less than $\$ 400$ million USD) to reduce default risk through scale effects and geographic diversification. The authors conclude that benefits of geographic diversification for small community banks are small. As idiosyncratic risk dominates local market risk in small community banks, they could reduce failure risk through increasing size, by acquiring other banks in the same market they operate. However, for small community banks located in urban markets, benefits of geographic diversification are greater, reflecting higher heterogeneity in economic conditions across U.S. urban areas than rural areas.

The 2008 global financial crisis has renewed the debate on the potential dark side of geographic diversification through spillover effects of local economic shocks by multi-market banks. As pointed out by Morgan et al. (2004), the extent to which geographic expansion reduces or increases the exposure to state-level economic volatility depends on whether loan demand shocks versus loan supply shocks predominate on the local market. When large loan losses occur on a local market, the presence of multi-market banks will reduce the sensitivity of the local market to such shocks. Multi-market banks could indeed maintain lending either because they have greater access to capital markets than single-market banks or because they can shift funds from their other markets. On the other hand, in the presence of demand-side shocks, such as a reduction in local borrowers' creditworthiness or a reduction in local loan demand, the behavior of multi-market banks will tend to amplify local shocks. As the perceived profitability of local lending decreases, multi-market banks will shift funds to the other markets where they operate. Evidence of a positive effect of geographic expansion are found by Strahan (2003), Becker (2007) and Keeton (2009), supporting the view that the shift to multi-market banking has reduced the overall sensitivity of bank lending to local economic shocks. However, investigating the effects of the housing market collapse in 2007-2008, Berrospides et al. (2013) find evidence of spillover effects of local economic shocks by multi-market banks.

Our aim is to investigate whether greater geographic diversification has been associated with higher risk-adjusted returns and to what extent banks' choices have impacted their default risk. As geographic diversification and size are different but interrelated dimensions, we 
investigate whether the benefits of getting wider differ across bank size. We expect a positive relationship between diversification and risk-adjusted returns, but the relationship at one or the other extreme (the initial step away from mono-market banking or the giant step towards nationwide banking) is undetermined. Moreover, spreading across counties and across states is motivated by developing banking activities in locations with different economic environments and non-synchronized fluctuations in economic conditions. Disparities in local economic conditions should be beneficial and therefore taken into account when assessing the effect of geographic diversification on banks' risk-adjusted returns. We expect risk-adjusted return to be improved by intrastate geographic diversification when economic disparities within the state increase. Consequently, bank default risk might be lower if banks do not switch towards riskier strategies. We also expect the same effect for interstate diversification when economic disparities across states are higher. However, at its first stages, bank diversification is more likely to occur in adjacent counties/states with similar patterns of returns (Emmons et al. (2004)). Consequently, the risk-return tradeoff might not be improved at the first stages of geographic diversification and the full benefits might only occur when banks reach more distant markets with less correlated economic conditions. Conversely, as argued above and supported by recent literature, the agency and learning costs induced by distance could also limit the potential benefits of moving to distant markets.

\section{Data}

\subsection{Data and sample}

Data are obtained from two main sources: Call Reports and FDIC's Summary of Deposits (SOD). The measures of geographic diversification used in this paper are based on bank branches' deposit dispersion as in Deng and Elyasiani (2008), Goetz et al. (2013) and Goetz (2012).

The initial sample of banks covers the 1994-2008 period. It's an unbalanced panel of 10681 banks with a total of 92550 annual observations. We measure all variables at the holdingcompany level, i.e. we treat all the commercial banks affiliated with a holding company as a 
single entity. ${ }^{7}$ Measuring the variables at the individual bank level would ignore the diversification provided via affiliation with banks in other locations. We exclude credit card banks, wholesale banks, or other special purpose entities. Diversification may matter for such institutions, but because they do not operate deposit networks, deposit data are not a good proxy of geographic diversification. ${ }^{8}$ We exclude BHCs that have not filed Call Reports for at least five years. To take bank mergers and acquisitions into consideration, we identify banks whose total assets have grown by more than $30 \%$ between any two consecutive years ( $\mathrm{t}-1$ and $\mathrm{t})^{9}$ and construct a dummy variable which is equal to 1 in year $t$ and the two following years (that we consider as a transitory period) and equal to 0 elsewhere. We conduct all our estimations excluding these three-year windows because we use the time dimension to compute some of our risk measures (rolling-window standard deviations).

\subsection{Diversification measures and their trends}

Geographic diversification for bank $^{10} \mathrm{i}$ in year $\mathrm{t}$, GEODIV $\mathrm{it}_{\mathrm{i}}$,equals:

$$
\text { GEODIV }_{\text {it }}=1-\Sigma_{\mathrm{j}}\left(\text { Deposits }_{\mathrm{j}} / \text { Total deposits }^{2}\right.
$$

Where Deposits $\mathrm{j}_{\mathrm{j}}$ measures the deposits of bank i in location $\mathrm{j}$ at time and Total deposits, the total deposits of bank $i$ at time $t$.

The GEODIV indexes vary between 0 - a BHC with all its deposits in branches in the same location - to one - a bank with its deposits spread widely across branches in (infinitely) many locations. The branch level data on deposits are from the annual Summary of Deposits collected by the Federal Deposit Insurance Corporation. Note that we are using deposits as a proxy for

\footnotetext{
${ }^{7}$ We aggregate data for commercial banks that are affiliated with the same holding company into BHC-level measures for each "market". For commercial banks that are the holding company (i.e., the only commercial bank affiliate), the BHC and bank data are the same.

${ }^{8}$ To identify wholesale banks, we use information reported for the purposes of the Community Reinvestment Act (CRA) that identifies whether an institution is considered a wholesale bank in the context of CRA assessments. The Home Mortgage Disclosure Act (HMDA) and CRA data are calendar year data. Here we also use year-end BHC data. Since the Summary of Deposits (SOD) data are reported for June of each year, we merger adjust these data to reflect the year-end bank and BHC-affiliates status before constructing our geographic diversification indices.

${ }^{9}$ To identify banks involved in mergers, we follow a criterion similar to that of Stiroh and Rumble (2006). They exclude from their sample observations for banks that have experienced a growth in total assets higher than $20 \%$ between two consecutive periods.

${ }^{10}$ Unless otherwise noted, in the rest of the paper, we use interchangeably the words bank and BHC.
} 
lending; deposits are not a perfect proxy for loans. Unfortunately U.S. banks do not report comprehensive information on where they lend. ${ }^{11}$

We measure geographic diversification at two different levels of detail on location. The first and finest measure, GD1 counts individual Metropolitan Statistical Area (MSAs) and all non-MSA counties as 2600 separate entities. This measure corresponds to the "local market" concept used in antitrust analysis and the literature on market structure and performance. The second measure, GD2, counts states as separate entities, with MSA and non-MSA counties within each state lumped together. In comparison with previous studies on geographic diversification, which either focus on the diversification behavior of listed banks (Deng and Elyasiani (2008) and Goetz et al. (2013) or on the effect of intrastate diversification on (small) banks located in one state (Goetz (2012)), our aim is to provide a broad picture of bank geographic diversification and to investigate the effect of both intrastate and interstate diversification of U.S. banks. Comparing the relationship between each measure and risk and returns will reveal whether the gains from diversification come from spreading across states, or whether there are also gains from spreading within states as well.

Table 1.1 highlights a strong heterogeneity of geographic diversification behavior across time.

\section{Insert Table 1.1}

The average U.S. bank has become wider since 1994 (Figure 1). The mean of GD1, the geographic diversification index over individual MSAs and rural counties, increased from 0.104 in 1994 to 0.208 in 2008, an increase of 100 percent. The broader measure of diversification GD2 also increased very sharply (117.3 percent) indicating stronger interstate expansion during the period. In 2008, more than 50 percent of the banking institutions in our sample still operate in a single county and more than 75 percent in a single state.

\section{Insert Figure 1}

\footnotetext{
${ }^{11}$ Banks do report application-level data on home mortgage applications, but many home mortgages are sold in the secondary mortgage market instead of being held in the originating bank's portfolio. Banks also report census tractlevel data on small loans originated to businesses and farms. However, small banks are not required to report these data.
} 
A look at the whole sample of banks over the 1994-2008 period shows that on average, more than half of the banks conduct their activities in a single county and more than $90 \%$ are located in a single state.

To disentangle the effect of geographic diversification and size within relatively homogenous bank subsets, we assess the effect of geographic diversification on the risk-return tradeoff using three sub-samples of banks. We consider three types of banks: small banks, large banks and very large banks. Following the literature, small banks are those with total assets below or equal to $\$ 1$ billion. Most of them are community banks, roughly defined in the literature as institutions with total assets below $\$ 1$ billion and that are essentially focused on relationship lending (see DeYoung et al., 2004 for a survey on this question). ${ }^{12}$ During the second part of the 1990s, a broad process of consolidation occurred in the U.S. banking industry during which most mergers involved two community banks or had a community bank as a target (DeYoung and Hunter, 2003). Despite this process which lead both to an increase in average bank size ${ }^{13}$ and to a reduction in community banks' market share, community banks still play an important role in relationship lending to small businesses. We consider two subsets for large banks. After the 2008 financial crisis the Federal Reserve has distinguished very large and systemically important institutions from other large banks with a threshold of $\$ 50$ billion (FED, 2011). We hence consider a sub-sample of large banks (total assets above $\$ 1$ billion and below $\$ 50$ billion) and a sub-sample of very large banks (total assets of $\$ 50$ billion and above). In line with the literature on the scale benefits of consolidation which highlights rapid diseconomies before assets reach the multi-billion dollar range, we expect the benefits of intrastate and interstate geographic diversification to be different at one or the other extreme in terms of bank size.

\footnotetext{
${ }^{12}$ As pointed out in DeYoung et al. (2004), bank size is not the only criterion to take into account to characterize an institution as a community bank; geographic concentration (single county for the smallest or single state for the largest), range of services and ownership structure (independent and domestically-owned) have also been taken into account to define a financial institution as a community bank.

${ }^{13}$ The number of U.S. banks with assets below \$1 billion declined from 14078 in 1980 to 7631 in 2001 and their market share fell from $33.4 \%$ to $16 \%$.
} 


\subsection{Bank profitability and risk measures}

To measure bank profitability, we use the return on assets $\left(\mathrm{ROA}_{\mathrm{it}}\right)$ and the return on equity $\left(\mathrm{ROE}_{\mathrm{it}}\right)$ :

$$
\begin{aligned}
\text { ROA }_{\text {it }} & =\frac{\text { Net income }_{\text {it }}}{\text { Total assets }_{\text {it }}} \\
\text { ROE }_{\text {it }} & =\frac{\text { Net income }_{\text {it }}}{\text { Total equity }} \text { it }
\end{aligned}
$$

To measure bank risk-taking we use the standard deviation of the return on assets, $\left(\mathrm{SdROA}_{\mathrm{it}}\right)$ and the standard deviation of the return on equity, $\left(\mathrm{SdROE}_{\mathrm{it}}\right)$ computed on a rolling window of 3 years. ${ }^{14}$

To measure risk-adjusted return we compute the ratio of $\mathrm{ROA}_{\mathrm{it}}$ to its standard deviation $\mathrm{SdROA}_{\mathrm{it}}, \mathrm{RaROA}_{\mathrm{it}}$ and the ratio of $\mathrm{ROE}_{\mathrm{it}}$ to its standard deviation $\mathrm{SdROE}_{\mathrm{it}}, \mathrm{RaROE}_{\mathrm{it}}$ :

$$
\begin{aligned}
\operatorname{RaROA}_{i t} & =\frac{\mathrm{ROA}_{\text {it }}}{\mathrm{SdROA}_{\text {it }}} \\
\operatorname{RaROE}_{i t} & =\frac{\mathrm{ROE}_{\text {it }}}{\operatorname{SdROE}_{\text {it }}}
\end{aligned}
$$

We also consider a measure of bank default risk by computing a 3-year rolling Z-score defined as:

$$
Z_{i t}=\frac{\overline{\operatorname{ROA}_{1 t}}+\overline{\text { EQUITY }_{1 t}}}{\text { SdROA }_{i t}}
$$

where EQUITY is the ratio of Total equity to Total assets; $\overline{\mathrm{ROA}}$ and $\overline{\mathrm{EQUITY}}$ are backward moving averages of ROA and EQUITY on a 3-year rolling window. The Z-score indicates the number of standard deviations that a bank's ROA has to fall below its expected value before equity is depleted. Thus, a higher value of $\mathrm{Z}$ is associated with a lower default probability.

\footnotetext{
${ }^{14}$ The rolling windows cover for year $\mathrm{t}$, year $\mathrm{t}$ and the previous two years.
} 
In our regressions, we exclude observations below the $1^{\text {st }}$ and above the $99^{\text {th }}$ percentile of our bank profitability, risk-adjusted returns and bank risk measures to mitigate the influence of outliers. We hence end up with a panel of 6532 banks and a total of 74054 observations.

\subsection{Indicators of disparities in economic conditions within/across states}

To assess whether banks actually benefit from disparities in economic conditions when they spread their activities in new markets across counties and states, we construct indicators of economic disparities within and across states.

To compute these indicators, we use annual information on county-level and state-level unemployment rates. A higher dispersion in the unemployment rate within the state or across states measured at a given date is used as a proxy of higher economic disparities within the state/across states. Our measure of 'within-state' economic disparities, SdUnempSt $t_{\mathrm{st}}$, is the dispersion of unemployment rates across the counties of a given state $s$ at time t. Similarly, our measure of 'across-states' economic disparities, SdUnempCtry, is the dispersion of unemployment rates across U.S. states at time t. The measure of dispersion we use is the standard deviation of the unemployment rate at a given date.

Interacting these indicators with the diversification variables $\left(\mathrm{GD}_{\mathrm{it}} * \mathrm{SdUnempSt}_{\mathrm{st}}\right.$ and GD2 ${ }_{\mathrm{it}}{ }^{*}$ SdUnempCtry $\mathrm{t}_{\mathrm{t}}$ ) aims to capture the impact of larger disparities in economic conditions within and across states on the benefits of geographic diversification. We expect the benefits of geographic diversification to be higher in the presence of larger disparities. Because we do not know the composition of the bank's loan portfolio and hence the geographic location of its customers, our state-level indicator is matched with our bank-level geographic diversification measures according to the location of the bank' headquarter.

\subsection{Other explanatory and control variables}

Other bank-specific variables are included as control variables $\left(\mathrm{CONTROL}_{\mathrm{it}}\right)$, to account for differences in portfolio diversification and functional diversification. Two product diversification indexes $\left(\mathrm{LOAN}_{\mathrm{it}}\right.$ and FOREIGN $\left.\mathrm{it}_{\mathrm{it}}\right)$ and one functional diversification index $\left(\mathrm{INCOME}_{\mathrm{it}}\right)$ are computed. Diversification indexes across the major loan categories $\left(\mathrm{LOAN}_{\mathrm{it}}\right)$, 
across foreign and domestic loans $\left(\right.$ FOREIGN $\left.{ }_{i t}\right)$, and across interest and non-interest income sources $\left(\mathrm{INCOME}_{\mathrm{it}}\right)$ for each bank, $\mathrm{i}$, in each year, $\mathrm{t}$, are measured analogously:

$\mathrm{LOAN}_{\mathrm{it}}=1-\Sigma_{\mathrm{j}=1-6}^{\mathrm{j}}\left(\text { Loans }_{\mathrm{j}} / \text { Total loans }\right)^{2}$

FOREIGN $_{\text {it }}=1-(\text { Foreign loans/Total loans })^{2}+(\text { Domestic loans/Total loans })^{2}$

$\mathrm{INCOME}_{\mathrm{it}}=1-(\text { Non-interest income } / \text { Income })^{2}+(\text { Interest income } / \text { Income })^{2}$

Loan diversification $\left(\mathrm{LOAN}_{\mathrm{it}}\right)$ is measured across the six major loan categories (Loans $\mathrm{j}$ ) reported in the Call Reports: commercial and industrial, commercial real estate, home mortgages, consumer, agricultural, and other. The non-interest activities measured by $\mathrm{INCOME}_{\mathrm{it}}$ include any fee-generating activities by banks (as opposed to interest), e.g. underwriting, payment services, trading activities.... Radecki (1999) documents the sizable shift toward such activities, especially by larger banks. Stiroh (2004a and b), Stiroh (2006) and Stiroh and Rumble (2006) report that a higher share of non-interest income in total income positively affects the volatility of bank returns inducing higher risk. In principle, foreign diversification $\left(\right.$ FOREIGN $\left._{i t}\right)$ should operate on risk and return in the same way as domestic diversification across the U.S.. We also include

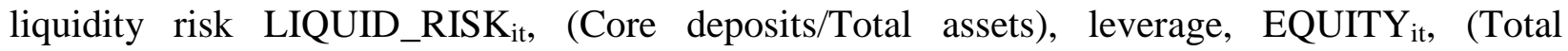
equity/Total assets) and Credit risk, CRED_RISK it $_{\text {, }}$ (Net charges off of loans and leases/Total loans) ${ }^{15}$ in the estimations.

Dummy variables are also included to identify the main bank loan specialization (agricultural loan, mortgage specialists, consumer-oriented...) and to distinguish some specific types of banks (banks which are part of a holding company from independent banks and agricultural lending institutions). We also take into account the specific characteristics of our sample regarding geographic diversification/concentration. Because more than half of the banks in our sample operate in a single county and more than $90 \%$ are located in a single state, we include in our estimations two dummy variables which take the value of 1 if the bank is located in a single county or a single state respectively. Apart from time effects, we also include a

\footnotetext{
${ }^{15}$ We also run regressions from which CRED_RISK $\mathrm{it}$ is excluded from the set of explanatory variables.
} 
dummy variable which takes the value of 1 in 2007 and 2008 and 0 before to account for the specific effect of the 2007-2008 global financial crisis. Finally, while these time effects are constant across banks but could differ across states, we also add the growth rate of the real gross domestic product of state $\mathrm{s}$ at time $\mathrm{t}\left(\mathrm{GROWTH}_{\mathrm{st}}\right)$ and the standard deviation of the unemployment rate within the state where the bank's headquarter is located $\left(\mathrm{SdUnempSt}_{\mathrm{st}}\right)$ to account for differences in economic conditions across U.S. states.

Tables 1.2 to 1.5 provide descriptive statistics for the whole sample and for our three subsamples (small banks, large banks and very large banks).

\section{Insert Tables 1.2 to 1.5}

The descriptive statistics highlight a strong heterogeneity across banks in terms of geographic expansion. More than $50 \%$ of small banks are located in a single county and more than $90 \%$ operate in a single state only. Conversely, very large banks are all located in more than one state. In between, more than half of large banks are present in more than one state.

The correlation matrices among our major variables highlight a positive correlation between geographic diversification and size as one would expect (Tables 2.1 and 2.2).

\section{Insert Tables 2.1 and 2.2}

To deal with co-linearity issues, we orthogonalize the logarithm of total assets, with each of our two geographic diversification indexes and use the residuals as our bank size proxy (SIZE). ${ }^{16}$

\footnotetext{
${ }^{16}$ For example, when considering geographic diversification across rural and MSA counties, GD1, we regress the logarithm of total assets on GD1 and use the residuals as a proxy of size.
} 


\section{Econometric methodology and results}

\subsection{Econometric methodology}

Our baseline model is as follows:

$$
\begin{aligned}
& \mathrm{Y}_{\mathrm{it}}=\propto_{\mathrm{i}}+\propto_{\mathrm{T}}+\beta_{1} \text { GEODIV }_{\mathrm{it}}+\beta_{2} \mathrm{GEODIV}_{\mathrm{it}}{ }^{2}+\theta_{1} \operatorname{SIZE}_{\mathrm{it}}+\gamma_{1} \mathrm{GEODIV}_{\mathrm{it}} * \operatorname{SDUNEMP}_{\mathrm{t}}+\gamma_{2} \mathrm{GEODIV}_{\mathrm{it}}{ }^{2} * \operatorname{SDUNEMP}_{\mathrm{t}}+ \\
& \delta \mathrm{CONTROL}_{\mathrm{it}}+\varepsilon_{\mathrm{it}}
\end{aligned}
$$

$Y_{\text {it }}$ is either a measure of profitability, risk-adjusted return, risk-taking or default risk of bank $i$ at time t, GEODIV $\mathrm{it}_{\mathrm{it}}$ is one of the two indicators of geographic diversification of bank $\mathrm{i}$ at time $\mathrm{t}\left(\mathrm{GD} 1_{\mathrm{it}}\right.$ or $\left.\mathrm{GD} 2_{\mathrm{it}}\right)$ and $\mathrm{SIZE}$ it is an indicator of bank size of bank $\mathrm{i}$ at time $\mathrm{t}$. We use our bank size measure from which the impact of geographic diversification has been pulled out. Each geographic diversification index is separately included as well as its squared value; we also interact the geographic diversification index and its squared value with its corresponding (statelevel or nationwide) measure of disparities in economic conditions, $\operatorname{SDUNEMP}_{\mathrm{t}}\left(\mathrm{SdUnempSt}_{\mathrm{st}}\right.$ or SdUnempCtry $y_{t}$. These interaction terms capture the influence of within/across states disparities in economic conditions on the benefits of geographic diversification. The intrastate geographic diversification index $\left(\mathrm{GD}_{\mathrm{it}}\right)$ is interacted with $\mathrm{SdUnempSt}_{\mathrm{st}}$, our state-level indicator of economic dispersion which measures the dispersion of unemployment rates across the counties of a given state, $s$, at time $t$. The interstate geographic diversification index (GD2 $\left.2_{i t}\right)$ is interacted with SdUnempCtry ${ }_{t}$, our country-level indicator of economic dispersion, which measures the dispersion of unemployment rates across U.S. states at time t. $\alpha_{\mathrm{i}}$ and $\alpha_{\mathrm{T}}$ are respectively the individual effects and time-specific effects.

Our baseline model accounts for possible $U$ or humped shaped relationships between geographic diversification and the dependent variable (either profitability, risk-adjusted return, risk-taking or default risk) at different levels of size and economic conditions. As argued above, while spreading across new markets should be beneficial in terms of risk-adjusted return (portfolio diversification gains), it could also have some negative effects due to larger distance from headquarters (information costs and agency costs). Moreover, differences in size and business model could also impact geographic diversification benefits. Lending technologies 
which rely on soft information are less extendable than those based on hard information. Hence, when expanding beyond their core market, small banks and more specifically community banks specialized in relationship lending may face higher costs than larger banks which rely on transaction-based lending technologies.

In order to assess whether the benefits of geographic diversification outweigh its costs, we estimate the marginal effect of geographic diversification i.e. the first derivative of $Y_{i t}$ with respect to the geographic diversification index $\left(\right.$ GEODIV $\left._{\mathrm{it}}\right)$ :

$\frac{\partial Y_{\text {it }}}{\partial \text { GEODIV }_{\text {it }}}=\beta_{1}+2 \beta_{2} \overline{\text { GEODIV }}+\gamma_{1} \overline{\text { SDUNEMP }}+2 \gamma_{2} \overline{\text { GEODIV }} * \overline{\text { SDUNEMP }}$

The value of the marginal effect of geographic diversification on $Y_{i t}$ is computed using the average value of the geographic diversification indicator ( $\overline{\text { GEODIV }}$ ) and of the disparities of economic conditions ( $\overline{\text { SDUNEMP }}$ ).

When significant non-linear effects are captured by our estimations, we further estimate the inflection point, GEODIV*, by taking the first derivative of $\mathrm{Y}_{\mathrm{it}}$ with respect to the geographic diversification index $\left(\right.$ GEODIV $\left._{\mathrm{it}}\right)$ defined in equation (2) and equalizing it to zero:

$\frac{\partial \mathrm{Y}_{\text {it }}}{\partial \mathrm{GEODIV}_{\mathrm{it}}}=0 \Leftrightarrow \mathrm{GEODIV}^{*}=-\frac{\beta_{1}+\gamma_{1} \overline{\text { SDUNEMP }}}{2\left(\beta_{2}+\gamma_{2} \text { (SDUNEMP }\right)}$

We run the regressions using a fixed effects model and regression errors are clustered at the bank level. We first estimate a model including only the geographic diversification indicator and its squared-value and include in a second step the interaction terms between the geographic diversification index and our indicators of economic disparities. In each step, we conduct estimations on the whole sample and on our three different sub-samples (small banks, large banks and very large banks).

The estimation results are reported in Tables 3, 4, 5 and $6 .^{17}$

\footnotetext{
${ }^{17}$ These tables report results with ROA and SdROA as the profitability and bank risk taking measures respectively. Considering ROE and SdROE provides similar findings. Results are available from the authors on request.
} 


\subsection{Geographic diversification and size}

Considering the whole sample of banks (Table 3), we first highlight a hump-shaped relationship between geographic diversification and risk-adjusted returns. Whatever its scope, geographic diversification improves the risk-return tradeoff of U.S. banks over the period under study.

At first stages of diversification, spreading across counties (GD1) or across states (GD2) allows banks to improve their risk-return tradeoff; however, when geographic diversification goes further up, this positive effect turns out to be negative. Spreading across rural and MSA counties (GD1) reduces banks' earnings volatility measured by the standard deviation of the return on assets, although only at the 10 percent significance level. As argued above, nonlinearity in the impact of geographic diversification could be explained by higher costs (agency costs and learning costs) faced by banks as they become more geographically-diversified. Whereas geographic expansion might improve the risk/return tradeoff at the first stages of diversification, spreading across more and more different markets make it more difficult for principals (executive managers located at the headquarter and owners of the bank) to monitor agents (managers of branches located in other counties or other states). Learning costs are also higher because of the lack of information when entering in a new market (Berger and DeYoung, 2001). The marginal effect of geographic diversification on profitability and risk-adjusted return is positive and significant for both intrastate and interstate diversification. ${ }^{18}$ Whatever its scope, geographic diversification is beneficial for U.S. banks over the period and, on average, U.S. banks are below the level of diversification for which the benefits are counterbalanced by the costs. $^{19}$

We then question whether the average (non-linear) benefits of geographic diversification on risk-adjusted return are impacted by differences in bank size (Table 4). We find intrastate and interstate geographic diversification to have a different effect on risk-adjusted return and bank

\footnotetext{
${ }^{18}$ For this specification of our baseline model including only the geographic diversification indicator and its squared value, the marginal effect and the inflection point are defined as follows:

$\frac{\partial \mathrm{Y}_{\text {it }}}{\partial \mathrm{GEODIV}_{\text {it }}}=\beta_{1}+2 \beta_{2} \overline{\mathrm{GEODIV}}$ and GEODIV ${ }^{*}=-\frac{\beta_{1}}{2 \beta_{2}}$

${ }^{19}$ For intrastate diversification, in our estimations, the costs are found to counterbalance the benefits when the level of diversification reaches a value of 0.45 (compared to an average level of intrastate geographic diversification of 0.14 over the whole sample) and for interstate diversification the inflection point is equal to 0.27 (compared to an average level of interstate diversification of 0.01 over the whole sample).
} 
risk according to bank size. Firstly, we find a hump-shaped relationship between intrastate diversification and both profitability and risk-adjusted return for small banks which further benefit from lower return's volatility, but this effect is only significant at the 10 percent level. At the other extreme, for very large banks (i.e. with total assets above $\$ 50$ billion) we find both intrastate and interstate diversification to improve the risk-return tradeoff. ${ }^{20} \mathrm{We}$ still find a humpshaped relationship between both intrastate and interstate expansion and risk-adjusted return. Finally, we do not find any significant effect for large banks (those with total assets ranging from $\$ 1$ billion to $\$ 50$ billion). While the marginal effect of intrastate diversification is positive and significant for small banks, this effect is not significant for very large banks. This result indicates that whilst intrastate expansion is still beneficial for the average small bank in our sample, the average very large bank has reached a level of geographic diversification such as the benefits of both intrastate and interstate diversification are now counterbalanced by their costs. With an average level of intrastate diversification of 0.13 , small banks are well below the optimal level of diversification estimated at 0.48 and could benefit from further intrastate diversification. On the contrary, for the sub-sample of very large banks, which already show a high level of intrastate and interstate diversification (respectively 0.78 and 0.64 ), further expansion would not improve their risk/return tradeoff, with an estimated inflection point for intrastate diversification of 0.70 and of 0.62 for interstate diversification. Such differences in the optimal level of diversification across bank size could be explained by differences in banks' business model. For small banks specialized in relationship lending, the optimal level of geographic diversification may be smaller than for large banks specialized in transaction-based lending.

Our results clearly highlight non-linearity in the impact of geographic diversification. Whereas at one extreme, intrastate geographic expansion positively impacts small banks' riskadjusted return and reduces their risk, at the other extreme, very large banks fully benefit from both intrastate and interstate diversification. But, in between, geographic diversification does not appear to be beneficial. Such limits in the benefits of geographic diversification for larger banks are consistent with the findings of Deng and Elyasiani (2008) who highlight a reduction in BHC value and an increase in bank risk with higher distance between headquarter and branches.

${ }^{20}$ The effect is significant when using RaROE as a measure of risk-adjusted return. 
Similar conclusions are highlighted by Goetz et al. (2013) who show that higher geographic diversification due to interstate deregulation is associated with a reduction in BHC value.

Regarding control variables, income diversification across interest and non-interest activities improves profitability, increases bank risk (volatility of returns and default risk) and reduces risk-adjusted returns. These results are in line with those obtained for U.S. banks by Stiroh (2006) and Stiroh and Rumble (2006). Moreover, higher diversification across different loan activities reduces bank profitability. As expected, foreign diversification reduces the volatility of returns and default risk. However, it does not impact risk-adjusted returns.

\section{3 Geographic diversification and disparities in economic conditions within and across} states

We now focus on the influence of disparities in economic conditions on the actual geographic diversification benefits by looking at the coefficients of the geographic diversification indexes interacted with the corresponding disparity indicator.

Considering first the whole sample of banks, the benefits of geographic diversification (in terms of risk-adjusted return) across rural and MSA counties (GD1) are reduced, although only at the 10 percent level, when disparities in economic conditions within states increase (GD*SdUNEMP negative and significant) (Table 5). However, as the level of diversification increases, we highlight a reversed effect (GD ${ }^{2} *$ SdUNEMP positive and significant). For intrastate diversification, in the presence of higher disparities, returns on assets do not as highly benefit from diversification and such a result holds for either initially low or high levels of diversification $\left(\mathrm{GD}^{2} *\right.$ SdUNEMP not significant). The marginal effect of intrastate expansion on risk-adjusted return is positive and significant. However, when comparing this value for both specifications of our baseline model (i.e. including or not the effect of disparities of economic conditions), the effect is smaller when taking into account the influence of economic disparities.

We take our investigation further by assessing potential differences across bank size (Table 6). For small banks, higher disparities in economic conditions within states (between counties) or between states does not impact the relationship between geographic diversification and risk-adjusted returns. For very large banks, whatever their scope, the benefits of geographic diversification are impacted by disparities in economic conditions and these effects are non- 
linear. In the presence of larger disparities, the negative effect of expansion across states on risk (earnings volatility) is reduced (GD*SdUNEMP is positive and significant). But as the level of interstate diversification increases, this effect tends to be lower $\left(\mathrm{GD}^{2} * \mathrm{SdUNEMP}\right.$ is significant), allowing banks to benefit from increased disparities in economic conditions across states. Riskadjusted return is negatively affected for very large banks. But, as they get more diversified which could mean that they are moving further away, risk-adjusted return is improved. However, the marginal effect is not significant.

According to our results, the relationship between geographic diversification and banks' risk-adjusted return and risk are non-linear and these relationships are impacted by the existence of economic disparities across counties or states where banks are located. Whereas entering in new markets (new counties or new states) improves a bank's risk/return tradeoff, this effect could have been weaker when the first steps of geographic diversification occurred across counties or across states with correlated economic conditions. This result is consistent with the U.S banking industry consolidation process which occurred during the second part of the 1990s. As pointed out by DeYoung and Hunter (2003), Berger et al. (2004) and Emmons et al., (2004), the bulk of mergers are "mini-mergers" which involved small/community banks, in most cases located nearby. Such an expansion allows banks to reduce their idiosyncratic risk. Moreover, as these new markets are nearby their own local market, banks do not face sharp increases in monitoring and learning costs. However, if these markets are very close, we can expect ups and downs in economic activity to be strongly correlated. ${ }^{21}$ The benefits of geographic diversification will then be incomplete. When banks expand in more distant new markets, agency and learning costs increase but the benefits of expanding in non-contiguous markets with non-synchronized economic conditions are higher. This might be the outcome of greater heterogeneity of economic conditions across U.S. urban areas than rural areas in line with the findings of Emmons et al. (2004) who find greater benefits of geographic diversification for urban community banks than for rural banks.

\footnotetext{
${ }^{21}$ Berger and DeYoung (2001) highlight the strong potential benefits of geographic diversification from crossregional consolidation indicating that banks have incentives to expand beyond contiguous markets into noncontiguous markets to capture additional diversification gains.
} 


\subsection{Robustness checks ${ }^{22}$}

Whilst we control for the effect of the global financial crisis of 2007-2008 by introducing a dummy variable, we also conduct our estimation over the 1994-2006 period, excluding the years 2007 and 2008. On the whole, our main findings are unaffected.

We also consider an alternative measure of intrastate diversification that counts the individual MSAs separately, but treats all non-MSA counties as a single entity, giving us 380 entities in total. Economic fluctuations may indeed be similar in adjacent rural counties and therefore spreading that way may not yield much diversification. While we do not find any significant effect for small banks, very large banks benefit from diversification across MSA counties.

We also define other size groups for our different subsamples of banks. We isolate a group of very small banks (with total assets below $\$ 500$ million) and a group of medium sized banks (with total assets between $\$ 1$ billion and $\$ 10$ billion). Again, our main findings remain the same.

As discussed in Goetz (2012), the decision to expand activities across counties or across states might not be strictly exogenous and therefore correlated with past and possibly current realizations of the errors term in equation (1). To deal with endogeneity issues, we estimate equation (1) using the instrumental variables method (IV). To instrument our geographic diversification measure (GD1 and GD2) and their squared value, we use the lagged values of both our geographic diversification measures and their squared values. We also use indicators which enable us to account for differences across U.S. states in intrastate and interstate branching restrictions. For our intrastate diversification indicator (GD1) we include the number of elapsed years since a state first started to remove its intrastate branching restrictions (Goetz (2012)). For our interstate diversification measure, we use the index of interstate branching restrictions computed by Rice and Strahan (2010). Indeed, the Interstate Banking and Branching Efficiency Act contained provisions which granted states the right to erect roadblocks to branch expansion. These differences in regulatory barriers across states could have affected bank competition and bank geographic diversification behaviors. Using this set of instruments, the results are similar to those obtained with the OLS estimator.

\footnotetext{
${ }^{22}$ The results of these estimations are not reported but are available from the authors on request.
} 


\section{Conclusion}

This paper contributes to the literature on bank diversification by focusing on the benefits of geographic diversification. Since 1994, U.S. banks have strongly expanded their activities across counties and across states. Our findings clearly highlight some benefits from being present in more counties within the same state as well as across states. We use detailed data covering the 1994-2008 period and consider bank geographic diversification from the extreme case of institutions with operations limited to a single location (individual Metropolitan Statistical area (MSA) or individual county) to the case where customers are reached nationwide. While (either intrastate or interstate) geographic diversification is, on the whole, beneficial in terms of riskadjusted return, the effects are non-linear and depend on bank size. While at first stages of diversification spreading across counties or across states improves banks' risk-adjusted return, this positive effect turns out to be negative when geographic diversification moves further up. For small banks (i.e. with total assets below $\$ 1$ billion), our results indicate that, on average, they still have not reached their optimal diversification level. Further expansion across new counties may therefore improve their risk-return tradeoff. At the other extreme, both local (at the MSA or county level) and global (nationwide) geographic diversification are beneficial for very large banks. However, moving further does not always provide additional benefits. Expanding activities towards markets with different economic conditions, as measured by the dispersion in unemployment rates, increases the benefits of diversification but not at initially relatively low levels of diversification. At initially low levels of diversification, larger differences in economic

conditions actually alter the benefits of geographic diversification but moving further is beneficial. Our results suggest that the agency costs of going far are, at some stage, counterbalanced by the pure portfolio benefits of diversification. 


\section{References}

Becker, B., 2007. Geographical Segmentation of US Capital Market. Journal of Financial Economics 85, 151-178.

Berger, A., N., DeYoung R., 2001. The Effects of Geographic Expansion on Bank Efficiency. Journal of Financial Services Research 19, 163-184.

Berger, A., N., DeYoung R., 2006. Technological progress and the geographic expansion of commercial banks. Journal of Money, Credit, and Banking 38 (6), 1483-1513

Berger, A., N., Demsetz, R., S., Strahan, P., E., 1999. The consolidation of the financial services industry: Causes, consequences, and implications for the future. Journal of Banking and Finance 23 (2-4), 135-194.

Berrospides, J., Black, L., Keeton, W., 2013. The Cross-Market Spillover of Economic Shocks through Multi-Markets Banks. Finance and Economics Discussion Series 2013-52, Board of Governors of the Federal Reserve System (U.S.).

Demsetz, R., S., Strahan, P., E., 1997. Diversification, Size, and Risk at Bank Holding Companies. Journal of Money, Credit, and Banking, 29.

Deng, S., E., Elyasiani, E., 2008. Geographic Diversification, Bank Holding Company Value and Risk. Journal of Money Credit and Banking 40 (6), 1217-38.

DeYoung, R., Evanoff, D., D., Molyneux, P., 2009. Mergers and Acquisition of Financial Institutions: A Review of the Post-2000 Literature. Journal of Financial Services Research 36, 87-110.

DeYoung, R., Hunter, W., C., 2003. Deregulation, the Internet, and the Competitive Viability of Large Banks and Community Banks. In Benton Gup (Eds.), The Future of Banking, Westport, CT/ Quorum Books, 173-202.

DeYoung, R., Hunter, W., C., Udell, G., 2004. The past, present, and probable future for community banks. Journal of Financial Services Research 25 (2/3).

Dietsch, M., Oung, V., 2001. The Formation of Large Banking Groups in France: Observed and Potential Effects on Costs, Income, and Risks. General Secretariat of the Banking Commission. 
Emmons, W. R., Gilbert, R., A., Yeager, T., J., 2004. Reducing the Risk at Small Community Banks: Is it Size or Geographic Diversification that Matters? Journal of Financial Services Research 25 (2/3), 259-281.

FDIC. 2002. FDIC Quarterly Banking Profile, Third Quarter.

Evanoff D., D., Ors, E., 2008. The Competitive Dynamics of Geographic Deregulation in Banking: Implications for Productive Efficiency. Journal of Money Credit and Banking 40 (5), 897-928.

Federal Register (2011), Proposed rules, Federal Reserve, 76, 7731-7740.

Feng, G., Serletis, A., 2009. Efficiency, technical change, and returns to scale in large US banks: Panel data evidence from an output distance function satisfying theoretical regularity. Journal of Banking and Finance 34 (1), 127-138.

Goetz, M., Laeven, L., Levine, R., 2013. The Valuation Effect of Geographic Diversification: Evidence from US Banks. Review of Financial Studies 26 (7), 1787-1823.

Goetz, M., 2012. Bank Diversification, Market Structure and Bank Risk Taking: Theory and Evidence from US Commercial Banks. Federal Reserve Bank of Boston Working Paper QAU122.

Houston, J., F., James, C., Marcus, D., 1997. Capital Market Frictions and the Role of Internal Capital Markets in Banking. Journal of Financial Economics 46 (2), 135-164.

Keeton, W., R., 2009. Has Multi-market Banking Changes the Response of Small Business Lending to Local Economic Shocks?. Economic Review, Federal Reserve Bank of Kansas City, First Quarter.

Laeven, L., Levine, R., 2007. Is there a diversification discount in financial conglomerates?. Journal of Financial Economics 85(2), 331-367.

Liang, N., Rhoades, S., A. 1998. Geographic Diversification and Risk in Banking. Journal of Economics and Business 40, 271-84.

Loutskina, E., Strahan, P., E., 2011. Informed and Uninformed Investment in Housing: The Downside of Diversification. Review of Financial Studies 24 (5), 1447-80.

McAllister, P., H., McManus, D., A., 1993. Resolving the Scale Efficiency Puzzle in Banking. Journal of Banking and Finance 17, 389-405. 
Meyers, A., P., Yeager, T., J., 2001. Are Small Rural Banks Vulnerable to Local Economic Downturns?. Federal Reserve Bank of St. Louis Review 83, 25-38.

Morgan, D., P., Rime, B., Strahan, P., E., 2004. Bank Integration and State Business Cycles Quarterly Journal of Economics 119 (4), 1555-1584.

Peristiani, S. 1997. Do Mergers Improve the X-Efficiency and Scale Efficiency of U.S. Banks? Evidence from the 1980s. Journal of Money, Credit, and Banking 29 (3), 326-337.

Rhoades, S., A., 1994. A Summary of Merger Performance Studies in Banking, 1980-1993, and an Assessment of the Operating Performance and Event Study Methodologies. Staff Economic Studies 167, Board of Governors of the Federal Reserve System, Washington, DC.

Rice, T., Strahan, P., E., 2010. Does Credit Competition Affect Small-Firm Finance?. Journal of Finance 65 (3), 861-889.

Stein, J., C., 2002. Information Production and Capital Allocation: Decentralized versus Hierarchical Firms. Journal of Finance 57(5), 1891-1921.

Stiroh, K., J., 2004a. Do community banks benefit from diversification?. Journal of Financial Services Research 25 (2-3), 135-160.

Stiroh, K., J., 2004b. Diversification in banking: is noninterest income the answer?. Journal of Money, Credit and Banking 36 (5), 853-882.

Stiroh, K., J., 2006. New Evidence on the Determinants of Bank Risk. Journal of Financial Services Research 30, 237-263.

Stiroh, K., J., Rumble, A., 2006. The dark side of diversification: the case of U.S. financial holding companies. Journal of Banking and Finance 30 (8), 2131-2161.

Strahan, P., E., 2003. The Real Effects of U.S. Banking Deregulation. Federal Reserve Bank of St. Louis Review 85 (4).

Yeager, T., J., 2004. The demise of community banks? Local economic shocks are not to blame. Journal of Banking and Finance 28, 2135-2153.

Wheelock, D., C., Wilson, P., W., 2001. New Evidence on Return to Scale and Product Mix Among U.S. Commercial Banks. Journal of Monetary Economics 47, 653-674.

Wheelock, D., C., Wilson, P., W., 2012. Do Large Banks have Lower Costs? New Estimates of Return to Scale for U.S. Banks. Journal of Money Credit and Banking 44 (1), 171-199. 
Graph 1: Intrastate and Interstate geographic diversification of US banks (1994 - 2008)

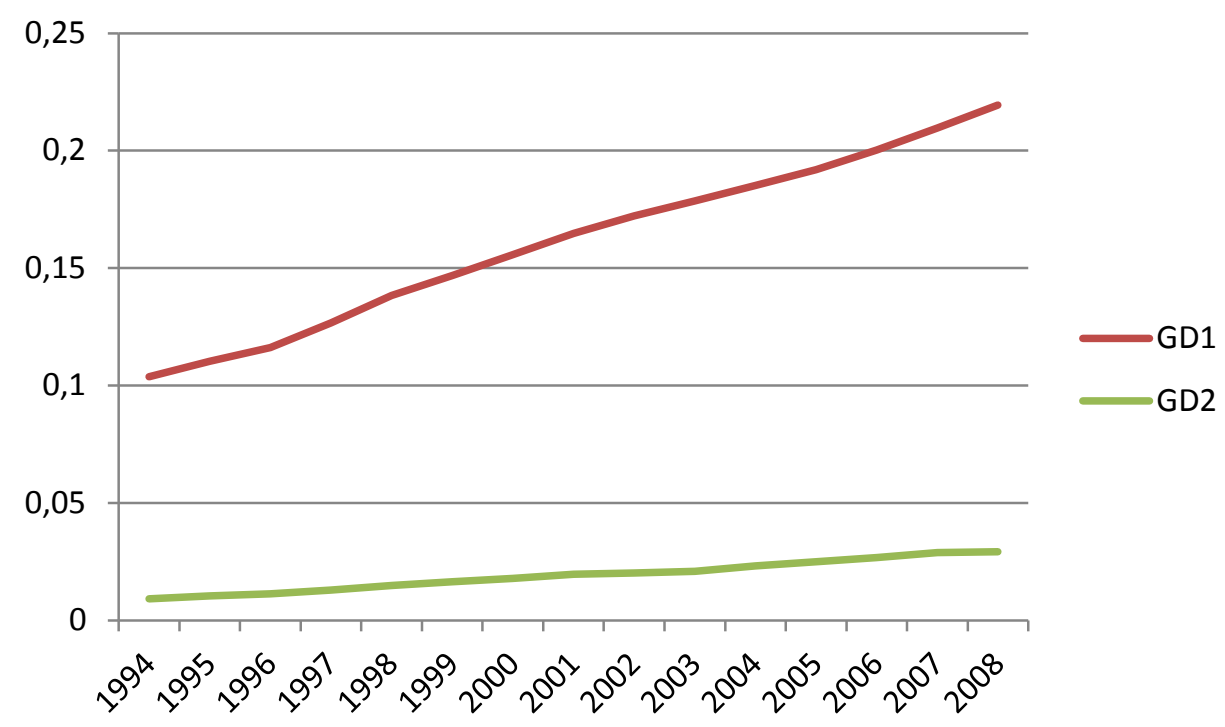

GD1: across rural and MSA counties geographic diversification index; GD2: across states geographic diversification index 
Table 1.1 Intrastate and Interstate diversification of U.S. banks

\begin{tabular}{|c|c|c|c|c|c|c|c|c|c|c|}
\hline \multicolumn{11}{|c|}{$1994-2008$} \\
\hline & Mean & $\begin{array}{l}\text { Standard } \\
\text { deviation }\end{array}$ & Minimum & Maximum & $\mathrm{p} 10$ & $\mathrm{p} 25$ & $\mathrm{p} 50$ & $\mathrm{p} 75$ & p90 & p99 \\
\hline GD1 & 0.146 & 0.237 & 0 & 0.978 & 0 & 0 & 0 & 0.275 & 0.520 & 0.852 \\
\hline GD2 & 0.0149 & 0.0796 & 0 & 0.918 & 0 & 0 & 0 & 0 & 0 & 0.481 \\
\hline$N$ & 74054 & & & & & & & & & \\
\hline \multicolumn{11}{|c|}{1994} \\
\hline & Mean & $\begin{array}{l}\text { Standard } \\
\text { deviation }\end{array}$ & Minimum & Maximum & $\mathrm{p} 10$ & $\mathrm{p} 25$ & $\mathrm{p} 50$ & $\mathrm{p} 75$ & p90 & p99 \\
\hline GD1 & 0.104 & 0.211 & 0 & 0.955 & 0 & 0 & 0 & 0 & 0.477 & 0.823 \\
\hline GD2 & 0.00923 & 0.0647 & 0 & 0.856 & 0 & 0 & 0 & 0 & 0 & 0.438 \\
\hline$N$ & 5074 & & & & & & & & & \\
\hline \multicolumn{11}{|c|}{2008} \\
\hline & Mean & $\begin{array}{l}\text { Standard } \\
\text { deviation }\end{array}$ & Minimum & Maximum & $\mathrm{p} 10$ & $\mathrm{p} 25$ & p50 & $\mathrm{p} 75$ & p90 & p99 \\
\hline GD1 & 0.208 & 0.268 & 0 & 0.965 & 0 & 0 & 0 & 0.438 & 0.627 & 0.886 \\
\hline GD2 & 0.0256 & 0.103 & 0 & 0.906 & 0 & 0 & 0 & 0 & $2.22 \mathrm{e}-16$ & 0.565 \\
\hline$N$ & 4248 & & & & & & & & & \\
\hline
\end{tabular}

GD1: across rural and MSA counties geographic diversification index; GD2: across states geographic diversification index; N: number of observations; pi: $i^{\text {th }}$ percentile. 
Table 1.2 Descriptive statistics - Whole sample (1994 - 2008)

\begin{tabular}{|c|c|c|c|c|c|c|c|c|c|}
\hline & Mean & $\begin{array}{c}\text { Standard } \\
\text { Deviation }\end{array}$ & Minimum & Maximum & p10 & p25 & $\mathrm{p} 50$ & p75 & p90 \\
\hline \multicolumn{10}{|c|}{ Bank-level variables } \\
\hline $\mathrm{ROA}$ & 0.0114 & 0.00525 & -0.0111 & 0.0283 & 0.00531 & 0.00840 & 0.0113 & 0.0143 & 0.0178 \\
\hline ROE & 0.113 & 0.0508 & -0.0399 & 0.265 & 0.0522 & 0.0802 & 0.111 & 0.144 & 0.180 \\
\hline SdROA & 0.00210 & 0.00213 & 0.000129 & 0.0165 & 0.000453 & 0.000803 & 0.00145 & 0.00258 & 0.00443 \\
\hline SdROE & 0.0207 & 0.0195 & 0.00175 & 0.127 & 0.00462 & 0.00798 & 0.0145 & 0.0262 & 0.0449 \\
\hline RaROA & 9.942 & 7.334 & 0.894 & 34.62 & 2.535 & 4.450 & 7.789 & 13.49 & 20.87 \\
\hline RaROE & 9.562 & 6.694 & 1.143 & 31.16 & 2.664 & 4.458 & 7.693 & 12.93 & 19.79 \\
\hline $\mathrm{Z}$ & 119.3 & 125.8 & 5.320 & 923.1 & 24.23 & 42.69 & 78.57 & 145.3 & 260.0 \\
\hline GD1 & 0.146 & 0.237 & 0 & 0.978 & 0 & 0 & 0 & 0.275 & 0.520 \\
\hline GD2 & 0.0149 & 0.0796 & 0 & 0.918 & 0 & 0 & 0 & 0 & 0 \\
\hline INCOME & 0.251 & 0.0913 & 0 & 0.500 & 0.138 & 0.186 & 0.244 & 0.309 & 0.374 \\
\hline FOREIGN & 0.000800 & 0.0161 & 0 & 0.500 & 0 & 0 & 0 & 0 & 0 \\
\hline LOAN & 0.692 & 0.108 & 0 & 1.000 & 0.551 & 0.656 & 0.723 & 0.764 & 0.790 \\
\hline CREDIT_RISK & 0.00276 & 0.00658 & -0.195 & 0.455 & -0.000248 & 0.000217 & 0.00126 & 0.00330 & 0.00715 \\
\hline EQUITY & 0.105 & 0.0347 & -0.0150 & 0.767 & 0.0740 & 0.0830 & 0.0966 & 0.118 & 0.147 \\
\hline LIQUID_RISK & 0.729 & 0.0952 & 0.00223 & 0.979 & 0.608 & 0.677 & 0.743 & 0.797 & 0.836 \\
\hline TA & 725581.7 & 15015442.4 & 1050 & 1746720425 & 21976 & 40095 & 82937.5 & 180606 & 421911 \\
\hline $\log (\mathrm{TA})$ & 11.44 & 1.273 & 6.957 & 21.28 & 9.998 & 10.60 & 11.33 & 12.10 & 12.95 \\
\hline \multicolumn{10}{|c|}{ State and country level macroeconomic variables } \\
\hline SdUnempSt & 2.180 & 1.147 & 0.100 & 8.136 & 0.980 & 1.367 & 1.987 & 2.762 & 3.619 \\
\hline SdUnempCtry & 1.572 & 0.292 & 1.201 & 2.230 & 1.276 & 1.363 & 1.500 & 1.718 & 2.165 \\
\hline GROWTH & 0.0444 & 0.0596 & -0.0483 & 0.379 & 0.00146 & 0.0140 & 0.0301 & 0.0511 & 0.0807 \\
\hline
\end{tabular}

ROA: Net income/Total assets; ROE: Net income/Total equity; SdROA is the 3-year window standard deviation of ROA ; SdROE is the 3-year window standard deviation of ROE; RaROA: ROA/SdROA; RaROE: ROE/SdROE; Z: 3-year rolling Z-score; GD1: across rural and MSA counties geographic diversification index; GD2: across states geographic diversification index; INCOME: diversification index across interest and non-interest income; FOREIGN: diversification index across domestic and foreign loans; LOAN: diversification index across major loans categories; CRED_RISK: Net charges off of loans and leases/Total loans; EQUITY: Total equity/Total assets; LIQUID_RISK: Core deposits/Total assets; TA: Total assets; $\log (\mathrm{TA})$ : natural logarithm of Total assets (TA); N: number of observations; n: number of banks; pi: ${ }^{\text {th }}$ percentile.

SdUnempCtry: Standard deviation of unemployment rates across the states at time $\mathrm{t}$; SdUnempSt: Standard deviation of unemployment rates across the counties of a given state s at time t; GROWTH: rate of growth of (real) gross domestic product of a given state $\mathrm{s}$ at time $\mathrm{t}$. 
Table 1.3 Descriptive statistics - Small banks (Total Assets $\leq \$ 1$ billion) $(1994-2008)$

\begin{tabular}{lccccccccc} 
& Mean & $\begin{array}{c}\text { Standard } \\
\text { Deviation }\end{array}$ & Minimum & Maximum & $\mathrm{p} 10$ & $\mathrm{p} 25$ & $\mathrm{p} 50$ & $\mathrm{p} 75$ & $\mathrm{p} 90$ \\
\hline ROA & 0.0113 & 0.00527 & -0.0111 & 0.0283 & 0.00527 & 0.00835 & 0.0112 & 0.0143 & 0.0178 \\
ROE & 0.113 & 0.0506 & -0.0399 & 0.265 & 0.0517 & 0.0795 & 0.110 & 0.143 & 0.179 \\
SdROA & 0.00212 & 0.00213 & 0.000129 & 0.0165 & 0.000460 & 0.000812 & 0.00146 & 0.00260 & 0.00446 \\
SdROE & 0.0208 & 0.0195 & 0.00175 & 0.127 & 0.00462 & 0.00801 & 0.0146 & 0.0263 & 0.0449 \\
RaROA & 9.852 & 7.288 & 0.894 & 34.62 & 2.521 & 4.419 & 7.710 & 13.34 & 20.68 \\
RaROE & 9.475 & 6.642 & 1.143 & 31.16 & 2.652 & 4.428 & 7.629 & 12.77 & 19.54 \\
Z & 118.8 & 125.6 & 5.320 & 923.1 & 24.20 & 42.54 & 78.16 & 144.5 & 258.6 \\
GD1 & 0.130 & 0.219 & 0 & 0.917 & 0 & 0 & 0 & 0.231 & 0.495 \\
GD2 & 0.00793 & 0.0535 & 0 & 0.686 & 0 & 0 & 0 & 0 \\
INCOME & 0.247 & 0.0889 & 0 & 0.500 & 0.136 & 0.184 & 0.241 & 0.304 & 0.366 \\
FOREIGN & 0.000374 & 0.0116 & 0 & 0.500 & 0 & 0 & 0 & 0 \\
LOAN & 0.691 & 0.109 & 0 & 1.000 & 0.548 & 0.654 & 0.722 & 0.763 & 0.789 \\
CREDIT_RISK & 0.00272 & 0.00662 & -0.195 & 0.455 & -0.000273 & 0.000195 & 0.00122 & 0.00326 & 0.00714 \\
EQUITY & 0.106 & 0.0349 & -0.0150 & 0.767 & 0.0743 & 0.0833 & 0.0972 & 0.119 & 0.148 \\
LIQUID_RISK & 0.734 & 0.0912 & 0.00293 & 0.979 & 0.617 & 0.683 & 0.746 & 0.799 & 0.837 \\
TA & 134304.8 & 156771.8 & 1050 & 998767 & 21534 & 38870 & 78455.5 & 160841.5 & 317767 \\
log(TA) & 11.29 & 1.025 & 6.957 & 13.81 & 9.977 & 10.57 & 11.27 & 11.99 \\
\hline N 71064 & $\mathrm{n}=6370$ & & & & & & 12.67 \\
\hline \hline
\end{tabular}

ROA: Net income/Total assets; ROE: Net income/Total equity; SdROA is the 3-year window standard deviation of ROA; SdROE is the 3-year window standard deviation of ROE; RaROA: ROA/SdROA; RaROE: ROE/SdROE; Z: 3-year rolling Z-score; GD1: across rural and MSA counties geographic diversification index; GD2: across states geographic diversification index; INCOME: diversification index across interest and non-interest income; FOREIGN: diversification index across domestic and foreign loans; LOAN: diversification index across major loans categories; CRED_RISK: Net charges off of loans and leases/Total loans; EQUITY: Total equity/Total assets; LIQUID_RISK: Core deposits/Total assets; TA: Total assets; $\log (\mathrm{TA})$ : natural logarithm of Total assets (TA); N: number of observations; n: number of banks; pi: $i^{\text {th }}$ percentile. 
Table 1.4 Descriptive statistics - Large banks ( $\$ 1$ Billion <Total assets < \$50 Billion) $(1994-2008)$

\begin{tabular}{lccccccccc} 
& Mean & $\begin{array}{c}\text { Standard } \\
\text { Deviation }\end{array}$ & Minimum & Maximum & p10 & p25 & p50 & p75 & p90 \\
\hline ROA & 0.0119 & 0.00466 & -0.0109 & 0.0276 & 0.00650 & 0.00962 & 0.0121 & 0.0145 & 0.0172 \\
ROE & 0.135 & 0.0496 & -0.0395 & 0.265 & 0.0735 & 0.108 & 0.136 & 0.167 & 0.196 \\
SdROA & 0.00177 & 0.00211 & 0.000129 & 0.0165 & 0.000339 & 0.000606 & 0.00111 & 0.00206 & 0.00382 \\
SdROE & 0.0196 & 0.0193 & 0.00175 & 0.127 & 0.00458 & 0.00736 & 0.0132 & 0.0242 & 0.0426 \\
RaROA & 12.32 & 8.115 & 0.895 & 34.34 & 3.071 & 5.854 & 10.52 & 17.66 & 24.87 \\
RaROE & 11.72 & 7.530 & 1.146 & 31.08 & 3.012 & 5.698 & 9.984 & 16.66 \\
Z & 133.0 & 131.1 & 5.339 & 921.3 & 26.13 & 48.38 & 91.83 & 166.6 & 23.30 \\
GD1 & 0.501 & 0.333 & 0 & 0.978 & 0 & 0.160 & 0.579 & 0.807 & 0.892 \\
GD2 & 0.156 & 0.218 & 0 & 0.861 & 0 & 0 & $2.22 \mathrm{e}-16$ & 0.286 & 0.505 \\
INCOME & 0.339 & 0.0946 & 0.0287 & 0.500 & 0.207 & 0.277 & 0.347 & 0.409 & 0.458 \\
FOREIGN & 0.00637 & 0.0396 & 0 & 0.496 & 0 & 0 & 0 & 0 \\
LOAN & 0.723 & 0.0905 & 0.0234 & 0.965 & 0.619 & 0.696 & 0.745 & 0.780 & 0.799 \\
CREDIT_RISK & 0.00347 & 0.00558 & -0.0159 & 0.0817 & 0.000288 & 0.000999 & 0.00216 & 0.00390 & 0.00700 \\
EQUITY & 0.0908 & 0.0239 & 0.0116 & 0.308 & 0.0694 & 0.0779 & 0.0868 & 0.0981 & 0.111 \\
LIQUID_RISK & 0.634 & 0.121 & 0.00223 & 0.895 & 0.493 & 0.573 & 0.648 & 0.715 & 0.772 \\
TA & 4919490.5 & 7264290.2 & 1000069 & 49711241 & 1111408 & 1359556 & 2114050 & 4854243 & 11780002 \\
log(TA) & 14.85 & 0.926 & 13.82 & 17.72 & 13.92 & 14.12 & 14.56 & 15.40 \\
\hline N 2833 & $\mathrm{n}=482$ & & & & & & 16.28 \\
\hline \hline
\end{tabular}

ROA: Net income/Total assets; ROE: Net income/Total equity; SdROA is the 3-year window standard deviation of ROA; SdROE is the 3-year window standard deviation of ROE; RaROA: ROA/SdROA; RaROE: ROE/SdROE; Z: 3-year rolling Z-score; GD1: across rural and MSA counties geographic diversification index; GD2: across states geographic diversification index; INCOME: diversification index across interest and non-interest income; FOREIGN: diversification index across domestic and foreign loans; LOAN: diversification index across major loans categories; CRED_RISK: Net charges off of loans and leases/Total loans; EQUITY: Total equity/Total assets; LIQUID_RISK: Core deposits/Total assets; TA: Total assets; $\log (\mathrm{TA})$ : natural logarithm of Total assets (TA); N: number of observations; n: number of banks; pi: $i^{\text {th }}$ percentile. 
Table 1.5 Descriptive statistics - Very large banks (Total assets $\geq \$ 50$ Billion) $(1994-2008)$

\begin{tabular}{lccccccccc} 
& Mean & $\begin{array}{c}\text { Standard } \\
\text { Deviation }\end{array}$ & Minimum & Maximum & p10 & p25 & p50 & p75 & p90 \\
\hline ROA & 0.0123 & 0.00369 & -0.00234 & 0.0257 & 0.00851 & 0.0107 & 0.0125 & 0.0145 & 0.0158 \\
ROE & 0.143 & 0.0423 & -0.0222 & 0.236 & 0.0920 & 0.125 & 0.148 & 0.169 & 0.190 \\
SdROA & 0.00224 & 0.00214 & 0.000203 & 0.0153 & 0.000528 & 0.000865 & 0.00168 & 0.00270 & 0.00481 \\
SdROE & 0.0232 & 0.0184 & 0.00184 & 0.0872 & 0.00470 & 0.00912 & 0.0175 & 0.0307 & 0.0517 \\
RaROA & 9.774 & 7.121 & 0.965 & 34.52 & 2.767 & 4.362 & 7.381 & 13.82 & 20.47 \\
RaROE & 10.48 & 7.753 & 1.254 & 30.95 & 2.955 & 4.260 & 7.515 & 15.73 \\
Z & 91.27 & 88.88 & 6.531 & 520.1 & 20.62 & 37.02 & 61.99 & 124.1 & 196.6 \\
GD1 & 0.780 & 0.269 & 0.0173 & 0.962 & 0.130 & 0.787 & 0.904 & 0.936 & 0.953 \\
GD2 & 0.643 & 0.252 & 0 & 0.918 & 0.197 & 0.587 & 0.746 & 0.809 & 0.856 \\
INCOME & 0.460 & 0.0376 & 0.275 & 0.500 & 0.407 & 0.442 & 0.468 & 0.490 & 0.498 \\
FOREIGN & 0.0930 & 0.156 & 0 & 0.500 & 0 & 0.00286 & 0.0195 & 0.0913 & 0.439 \\
LOAN & 0.777 & 0.0558 & 0.611 & 0.940 & 0.688 & 0.755 & 0.782 & 0.812 & 0.838 \\
CREDIT_RISK & 0.00567 & 0.00467 & 0.0000120 & 0.0316 & 0.00165 & 0.00261 & 0.00430 & 0.00697 & 0.0121 \\
EQUITY & 0.0875 & 0.0183 & 0.0534 & 0.163 & 0.0664 & 0.0756 & 0.0854 & 0.0960 & 0.108 \\
LIQUID_RISK & 0.504 & 0.134 & 0.120 & 0.866 & 0.319 & 0.450 & 0.536 & 0.579 & 0.640 \\
TA & 192681981.5 & 261717268.8 & 50073829 & 1746720425 & 55392628 & 66242755 & 92636000 & 179362000 & 472126081 \\
log(TA) & 18.63 & 0.823 & 17.73 & 21.28 & 17.83 & 18.01 & 18.34 & 19.00 & 19.97 \\
\hline N 157 & $\mathrm{~m}=27$ & & & & & & & & \\
\hline \hline
\end{tabular}

ROA: Net income/Total assets; ROE: Net income/Total equity; SdROA is the 3-year window standard deviation of ROA; SdROE is the 3-year window standard deviation of ROE ; RaROA: ROA/SdROA; RaROE: ROE/SdROE; Z: 3-year rolling Z-score; GD1: across rural and MSA counties geographic diversification index; GD2: across states geographic diversification index; INCOME: diversification index across interest and non-interest income; FOREIGN: diversification index across domestic and foreign loans; LOAN: diversification index across major loans categories; CRED_RISK: Net charges off of loans and leases/Total loans; EQUITY: Total equity/Total assets; LIQUID_RISK: Core deposits/Total assets; TA: Total assets; $\log (\mathrm{TA})$ : natural logarithm of Total assets (TA); N: number of observations; $\mathrm{n}$ : number of banks; pi: $\mathrm{i}^{\text {th }}$ percentile. 
Table 2.1: Correlation matrix (GD1)

\begin{tabular}{|c|c|c|c|c|c|c|c|c|c|c|}
\hline & GD1 & $\mathrm{CGD1}^{2}$ & Log(TA) & SIZE & INCOME & FOREIGN & LOAN & CREDIT_RISK & EQUITY & "LIQUID_RISK \\
\hline GD1 & 1 & & & & & & & & & \\
\hline GD1² & 0.951 & 1 & & & & & & & & \\
\hline $\log (\mathrm{TA})$ & 0.507 & 0.529 & 1 & & & & & & & \\
\hline SIZE & 0.12 & 0.175 & 0.920 & 1 & & & & & & \\
\hline INCOME & 0.213 & 0.217 & 0.325 & 0.278 & 1 & & & & & \\
\hline FOREIGN & 0.0179 & 0.0207 & 0.160 & 0.177 & 0.0803 & 1 & & & & \\
\hline LOAN & 0.170 & 0.164 & 0.194 & 0.146 & 0.261 & 0.0201 & 1 & & & \\
\hline CREDIT_RISK & 0.0216 & 0.0251 & 0.0144 & 0.00671 & 0.0794 & 0.0249 & 0.0249 & 1 & & \\
\hline EQUITY & -0.170 & -0.145 & -0.223 & -0.180 & -0.252 & -0.0232 & -0.182 & -0.0395 & 1 & \\
\hline LIQUID_RISK & -0.122 & -0.126 & -0.372 & -0.372 & -0.0768 & -0.195 & -0.0162 & -0.0469 & -0.142 & 1 \\
\hline
\end{tabular}

GD1: across rural and MSA counties geographic diversification index; GD12: squared value of GD1; Log(TA): natural logarithm of Total assets (TA); SIZE: orthogonalized value of $\log$ (TA) with GD1 as measure of geographic diversification; INCOME: diversification index across interest and non-interest income; FOREIGN: diversification index across domestic and foreign loans; LOAN: diversification index across major loans categories; CRED_RISK: Net charges off of loans and leases/Total loans; EQUITY: Total equity/Total assets; LIQUID_RISK: Core deposits/Total assets.

Table 2.2: Correlation matrix (GD2)

\begin{tabular}{|c|c|c|c|c|c|c|c|c|c|c|}
\hline & GD2 & $\mathrm{GD}^{2}$ & $\log (\mathrm{TA})$ & SIZE & INCOME & FOREIGN & LOAN & CREDIT_RISK & EQUITY & LIQUID_RISK \\
\hline GD2 & 1 & & & & & & & & & \\
\hline $\mathrm{GD} 2^{2}$ & 0.947 & 1 & & & & & & & & \\
\hline $\log (\mathrm{TA})$ & 0.444 & 0.422 & 1 & & & & & & & \\
\hline SIZE & 0.275 & 0.261 & 0.983 & 1 & & & & & & \\
\hline INCOME & 0.179 & 0.169 & 0.325 & 0.313 & 1 & & & & & \\
\hline FOREIGN & 0.103 & 0.101 & 0.160 & 0.151 & 0.0803 & 1 & & & & \\
\hline LOAN & 0.0716 & 0.0680 & 0.194 & 0.193 & 0.261 & 0.0201 & 1 & & & \\
\hline CREDIT_RISK & 0.0292 & 0.0289 & 0.0144 & 0.00953 & 0.0794 & 0.0249 & 0.0249 & 1 & & \\
\hline EQUITY & -0.0687 & -0.0569 & -0.223 & -0.226 & -0.252 & -0.0232 & -0.182 & -0.039 & 1 & \\
\hline LIQUID_RISK & -0.156 & -0.145 & -0.372 & -0.367 & -0.0768 & -0.195 & -0.0162 & -0.0469 & -0.142 & 1 \\
\hline
\end{tabular}

GD2: across state geographic diversification index; GD2: squared value of GD2; Log(TA): natural logarithm of Total assets (TA); SIZE: orthogonalized value of $\log (\mathrm{TA})$ with GD2 as measure of geographic diversification; INCOME: diversification index across interest and non-interest income; FOREIGN: diversification index across domestic and foreign loans; LOAN: diversification index across major loans categories; CRED_RISK: Net charges off of loans and leases/Total loans; EQUITY: Total equity/Total assets; LIQUID_RISK: Core deposits/Total assets. 
Table 3: Benefits of geographic diversification of U.S. banks (1994 - 2008)

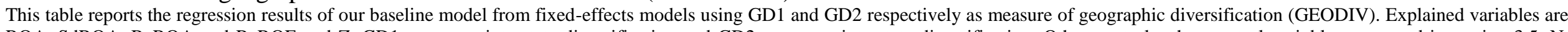

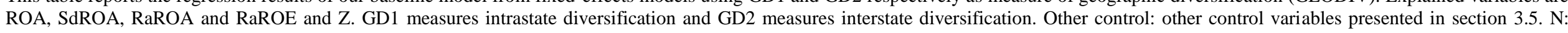

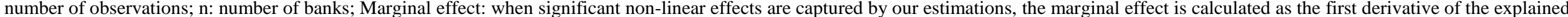

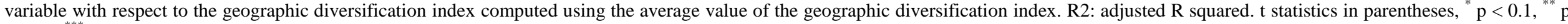
$<0.05,^{* * *} \mathrm{p}<0.01$. All other variables are defined in Table 1.1.

\begin{tabular}{|c|c|c|c|c|c|c|c|c|c|c|}
\hline & \multicolumn{5}{|c|}{ Intrastate diversification } & \multicolumn{5}{|c|}{ Interstate diversification } \\
\hline & ROA & RaROA & RaROE & SdROA & $\mathrm{Z}$ & ROA & RaROA & RaROE & SdROA & $\mathrm{Z}$ \\
\hline \multirow[t]{2}{*}{ GEODIV } & $0.00648^{* * * *}$ & $4.134^{* *}$ & $4.211^{* *}$ & $-0.00111^{*}$ & 19.59 & $0.00407^{* * * *}$ & $6.249^{*}$ & $7.432^{* * *}$ & $-0.00164^{*}$ & 64.93 \\
\hline & (7.26) & (1.98) & $(\mathbf{2 . 1 0})$ & $(-1.85)$ & $(0.63)$ & $(\mathbf{2 . 7 5 )}$ & (1.87) & $(2.28)$ & $(-1.93)$ & $(1.34)$ \\
\hline \multirow[t]{2}{*}{ GEODIV $^{2}$} & $-0.00560^{* * * *}$ & $-4.521^{*}$ & -3.663 & 0.00102 & -15.57 & -0.00275 & $-11.45^{* * *}$ & $-13.83^{* * *}$ & $0.00354^{* * *}$ & -139.7 \\
\hline & $(-5.08)$ & $(-1.71)$ & $(-1.40)$ & $(1.34)$ & $(-0.40)$ & $(-1.16)$ & $(-1.97)$ & $(-2.31)$ & $(2.37)$ & $(-1.54)$ \\
\hline \multirow[t]{2}{*}{ SIZE } & $0.00161^{* * * *}$ & $0.949^{* * * *}$ & $0.694^{* * * *}$ & $-0.000308^{* * * *}$ & $7.410^{*}$ & $0.00147^{* * * *}$ & $0.847^{* * * *}$ & $0.723^{* * *}$ & $-0.000304^{* * * *}$ & 7.579* \\
\hline & (11.19) & (3.43) & $(2.72)$ & $(-3.14)$ & (1.70) & $(\mathbf{1 0 . 9 5 )}$ & (3.25) & (2.99) & $(-3.27)$ & (1.87) \\
\hline \multirow[t]{2}{*}{ INCOME } & $0.00117^{* *}$ & $-4.836^{* * *}$ & -4.920 **** & $0.00198^{* * * *}$ & $-73.79^{3 * * *}$ & $0.00104^{* * *}$ & $-4.930^{* * * *}$ & $-4.902^{* * * *}$ & $0.00199^{* * * *}$ & $-74.10^{* * * *}$ \\
\hline & (2.23) & $(-5.48)$ & $(-5.86)$ & (6.49) & $(-5.56)$ & $(2.00)$ & $(-5.60)$ & $(-5.87)$ & $(6.53)$ & $(-5.61)$ \\
\hline \multirow[t]{2}{*}{ FOREIGN } & -0.00368 & -5.985 & -1.071 & $0.00547^{*}$ & -42.83 & -0.00332 & -7.206 & -3.420 & $0.00608^{* * *}$ & -64.07 \\
\hline & $(-0.86)$ & $(-1.11)$ & $(-0.18)$ & (1.96) & $(-0.82)$ & $(-0.79)$ & $(-1.24)$ & $(-0.54)$ & $(2.09)$ & $(-1.16)$ \\
\hline \multirow[t]{2}{*}{ LOAN } & $-0.00113^{* * *}$ & -0.114 & 0.0161 & -0.000140 & -4.331 & $-0.00115^{* * *}$ & -0.162 & -0.0194 & -0.000131 & -4.654 \\
\hline & $(-2.19)$ & $(-0.12)$ & $(0.02)$ & $(-0.45)$ & $(-0.29)$ & $(-2.23)$ & $(-0.17)$ & $(-0.02)$ & $(-0.42)$ & $(-0.31)$ \\
\hline \multirow[t]{2}{*}{ GROWTH } & $0.00289^{* * * *}$ & $2.499^{* * *}$ & $1.937^{*}$ & $-0.00205^{* * * *}$ & $68.86^{* * * *}$ & $0.00289^{* * * *}$ & $2.523^{* *}$ & $1.961^{*}$ & $-0.002066^{* * * *}$ & $69.16^{* * * *}$ \\
\hline & $(6.90)$ & $(2.23)$ & (1.87) & $(-8.31)$ & $(3.80)$ & $(6.91)$ & $(2.25)$ & $(1.90)$ & $(-8.34)$ & (3.82) \\
\hline \multirow[t]{2}{*}{ SdUnempSt } & $-0.000108^{* * * *}$ & $-0.203^{* *}$ & $-0.165^{* * *}$ & $0.0000991^{* * * *}$ & $-3.164^{* * *}$ & $-0.000112 * * *$ & $-0.207^{* * *}$ & $-0.165^{* *}$ & $0.000100^{* * * *}$ & $-3.183^{* * *}$ \\
\hline & $(-2.83)$ & $(-2.36)$ & $(-2.04)$ & (4.28) & $(-2.40)$ & $(-2.93)$ & $(-2.41)$ & $(-2.04)$ & (4.32) & $(-2.41)$ \\
\hline \multirow[t]{2}{*}{ EQUITY } & $0.0451^{* * * * *}$ & $17.79^{* * * *}$ & -1.071 & -0.00539 **** & $627.6^{* * * *}$ & $0.0447^{* * * *}$ & $17.53^{* * * *}$ & -1.069 & $-0.005433^{* * *}$ & $630.0^{* * * * *}$ \\
\hline & $(21.57)$ & $(5.38)$ & $(-0.37)$ & $(-4.79)$ & (10.97) & (21.30) & $(5.31)$ & $(-0.37)$ & $(-4.83)$ & (11.03) \\
\hline LIQUID_RISK & $(-0.38)$ & $(-1.29)$ & $(-0.75)$ & (3.28) & $(-1.85)$ & $(-0.68)$ & $(-1.40)$ & $(-0.72)$ & (3.32) & $(-1.85)$ \\
\hline CREDIT_RISK & $\begin{array}{c}-0.274^{* * *} \\
(-24.13)\end{array}$ & $\begin{array}{l}-204.3^{* * * *} \\
(-16.27)\end{array}$ & $\begin{array}{l}-189.3^{* * * *} \\
(-14.98)\end{array}$ & & & $\begin{array}{c}-0.274^{* * * *} \\
(-24.13)\end{array}$ & $\begin{array}{c}-204.2^{* * * *} \\
(-16.26)\end{array}$ & $\begin{array}{l}-189.3^{* * * *} \\
(-14.98)\end{array}$ & & \\
\hline \multirow[t]{2}{*}{ Constant } & $0.00763^{* * * *}$ & $9.642^{* * * *}$ & $10.71^{* * * *}$ & $0.00150^{* * * *}$ & $96.55^{* * * *}$ & $0.00849^{* * * *}$ & $10.06 * * *$ & $11.12^{* * * *}$ & $0.00138^{* * * *}$ & $97.56^{* * * *}$ \\
\hline & (12.22) & (7.91) & (9.32) & (4.02) & $(5.02)$ & (13.77) & $(8.69)$ & (10.17) & (3.87) & $(5.32)$ \\
\hline Other control & $\checkmark$ & $\checkmark$ & $\checkmark$ & $\checkmark$ & $\checkmark$ & $\checkmark$ & $\checkmark$ & $\checkmark$ & $\checkmark$ & $\checkmark$ \\
\hline Time effects & $\checkmark$ & $\checkmark$ & $\checkmark$ & $\checkmark$ & $\checkmark$ & $\checkmark$ & $\checkmark$ & $\checkmark$ & $\checkmark$ & $\checkmark$ \\
\hline $\mathrm{N}$ & 69911 & 50020 & 48271 & 57535 & 57524 & 69911 & 50020 & 48271 & 57535 & 57524 \\
\hline $\mathrm{N}$ & 6272 & 6150 & 6135 & 6215 & 6213 & 6272 & 6150 & 6135 & 6215 & 6213 \\
\hline $\mathrm{R} 2$ & 0.266 & 0.0386 & 0.0350 & 0.0435 & 0.0260 & 0.266 & 0.0386 & 0.0352 & 0.0437 & 0.0261 \\
\hline Marginal effect & .0048649 & 2.783368 & & & & & 5.908273 & 7.020246 & -.0015326 & \\
\hline z-statistic & $7.87 * * *$ & $1.99 * *$ & & & & & $1.85 *$ & $2.26 * *$ & $-1.89 *$ & \\
\hline
\end{tabular}


Table 4: Geographic diversification and bank size (1994 - 2008)

This table reports the regression results of our baseline model when including only geographic diversification index and its squared-value across three sub-samples of bank size (small banks $(\mathrm{TA} \leq \$ 1 \mathrm{~B})$; large banks $(\$ 1 \mathrm{~B}<\mathrm{TA}<\$ 50 \mathrm{~B})$; very large banks $(\mathrm{TA} \geq \$ 50 \mathrm{~B})$ from fixed-effects models using GD1 and GD2 respectively as measure of geographic diversification (GEODIV). Explained variables are ROA, SdROA, RaROA, RaROE and Z. GD1 measures intrastate diversification and GD2 measures interstate diversification. Other variables: other explanatory and control variables presented in section 3.5. N: number of observations; n: number of banks; Marginal effect: when significant non-linear effects are captured by our estimations, the marginal effect is calculated as the first derivative of the explained variable with respect to the geographic diversification index computed using the average value of the geographic diversification index. R2: adjusted R squared. t statistics in parentheses, ${ }^{*} p<0.1,{ }^{* *} p<0.05,{ }^{* * *} p<$ 0.01 . All other variables are defined in Table 1.1.

Small banks $(\mathrm{TA} \leq \$ 1 \mathrm{~B})$

\begin{tabular}{|c|c|c|c|c|c|c|c|c|c|c|}
\hline & \multicolumn{5}{|c|}{ Intrastate diversification } & \multicolumn{5}{|c|}{ Interstate diversification } \\
\hline & ROA & RaROA & RaROE & SdROA & $\mathrm{Z}$ & ROA & RaROA & RaROE & SdROA & $\mathrm{Z}$ \\
\hline GEODIV & $\begin{array}{c}0.00726^{* * *} \\
(7.25)\end{array}$ & $\begin{array}{c}\text { 6.126 }^{* * * *} \\
(2.75)\end{array}$ & $\begin{array}{c}4.327^{* * *} \\
(1.99)\end{array}$ & $\begin{array}{c}-0.00121^{*} \\
(-1.87)\end{array}$ & $\begin{array}{l}46.55 \\
(1.40)\end{array}$ & $\begin{array}{c}0.00552^{* * *} \\
(2.26)\end{array}$ & $\begin{array}{l}1.264 \\
(0.25)\end{array}$ & $\begin{array}{l}-0.982 \\
(-0.20)\end{array}$ & $\begin{array}{c}-0.000802 \\
(-0.46)\end{array}$ & $\begin{array}{l}-74.27 \\
(-0.84)\end{array}$ \\
\hline GEODIV $^{2}$ & $\begin{array}{c}-0.00594^{* * * *} \\
(-4.62)\end{array}$ & $\begin{array}{c}-6.275^{* * *} \\
(-2.17)\end{array}$ & $\begin{array}{l}-3.083 \\
(-1.05)\end{array}$ & $\begin{array}{c}0.000589 \\
(0.68)\end{array}$ & $\begin{array}{l}-28.82 \\
(-0.66)\end{array}$ & $\begin{array}{c}-0.00281 \\
(-0.56)\end{array}$ & $\begin{array}{l}7.593 \\
(0.67)\end{array}$ & $\begin{array}{l}12.60 \\
(1.18)\end{array}$ & $\begin{array}{c}-0.000788 \\
(-0.20)\end{array}$ & $\begin{array}{l}284.9 \\
(1.37)\end{array}$ \\
\hline SIZE & $\begin{array}{c}0.00189^{* * * *} \\
(11.13)\end{array}$ & $\begin{array}{c}1.347^{* * * *} \\
(4.72)\end{array}$ & $\begin{array}{c}1.063^{* * * *} \\
(4.11)\end{array}$ & $\begin{array}{c}-0.000464^{* * * *} \\
(-4.32)\end{array}$ & $\begin{array}{c}16.01^{* * *} \\
(3.51)\end{array}$ & $\begin{array}{c}\mathrm{O.00173}^{\text {**** }} \\
(\mathbf{1 1 . 0 4 )}\end{array}$ & $\begin{array}{c}1.122^{* * * *} \\
(4.13)\end{array}$ & $\begin{array}{c}0.977^{* * * * *} \\
(3.91)\end{array}$ & $\begin{array}{c}-0.000440 \\
(-4.41)\end{array}$ & $\begin{array}{c}14.69^{* * * *} \\
(3.40)\end{array}$ \\
\hline Constant & $\begin{array}{c}0.00765^{* * * *} \\
(11.80)\end{array}$ & $\begin{array}{c}8.826^{* * * *} \\
(7.10)\end{array}$ & $\begin{array}{c}10.66^{* * * *} \\
(9.15)\end{array}$ & $\begin{array}{c}0.00160^{* * * *} \\
(4.17)\end{array}$ & $\begin{array}{c}82.56^{* * * *} \\
(4.23)\end{array}$ & $\begin{array}{c}0.00857^{* * * *} \\
(13.33)\end{array}$ & $\begin{array}{c}9.642^{* * * *} \\
(8.16)\end{array}$ & $\begin{array}{l}11.28 \text { **** } \\
(10.16)\end{array}$ & $\begin{array}{c}\mathbf{0 . 0 0 1 4 3}^{* * * *} \\
(\mathbf{3 . 8 6})\end{array}$ & $\begin{array}{c}90.84^{* * * *} \\
(4.84)\end{array}$ \\
\hline Other variables & $\checkmark$ & $\checkmark$ & $\checkmark$ & $\checkmark$ & $\checkmark$ & $\checkmark$ & $\checkmark$ & $\checkmark$ & $\checkmark$ & $\checkmark$ \\
\hline Time effects & $\checkmark$ & $\checkmark$ & $\checkmark$ & $\checkmark$ & $\checkmark$ & $\checkmark$ & $\checkmark$ & $\checkmark$ & $\checkmark$ & $\checkmark$ \\
\hline $\mathrm{N}$ & 67287 & 48165 & 46444 & 55286 & 55266 & 67287 & 48165 & 46444 & 55286 & 55266 \\
\hline $\mathrm{N}$ & 6133 & 5948 & 5937 & 6018 & 6017 & 6133 & 5948 & 5937 & 6018 & 6017 \\
\hline R2 & 0.264 & 0.0379 & 0.0337 & 0.0426 & 0.0260 & 0.264 & 0.0377 & 0.0338 & 0.0426 & 0.0260 \\
\hline $\begin{array}{c}\text { Marginal effect } \\
\text { z-statistic }\end{array}$ & $\begin{array}{l}.0057281 \\
8.02 * * * *\end{array}$ & $\begin{array}{c}4.427658 \\
2.89 * * *\end{array}$ & & & & & & & & \\
\hline
\end{tabular}

Large banks $(\$ 1 \mathrm{~B}<\mathrm{TA}<\$ 50 \mathrm{~B})$

\begin{tabular}{|c|c|c|c|c|c|c|c|c|c|c|}
\hline & \multicolumn{5}{|c|}{ Intrastate diversification } & \multicolumn{5}{|c|}{ Interstate diversification } \\
\hline & ROA & RaROA & RaROE & SdROA & $\mathrm{Z}$ & ROA & RaROA & RaROE & SdROA & $\mathrm{Z}$ \\
\hline \multirow[t]{2}{*}{ GEODIV } & 0.00311 & -7.499 & 3.491 & -0.000433 & -120.2 & -0.00329 & 1.950 & 6.632 & -0.000375 & 181.7 \\
\hline & $(0.99)$ & $(-0.77)$ & $(0.35)$ & $(-0.21)$ & $(-0.77)$ & $(-1.19)$ & $(0.21)$ & $(0.92)$ & $(-0.23)$ & $(1.55)$ \\
\hline \multirow[t]{2}{*}{ GEODIV $^{2}$} & -0.00334 & 9.131 & -1.081 & 0.00167 & 88.14 & 0.00132 & -12.72 & -12.56 & 0.00215 & -311.4 \\
\hline & $(-1.08)$ & $(0.87)$ & $(-0.11)$ & $(0.77)$ & $(0.55)$ & $(0.42)$ & $(-1.09)$ & $(-1.28)$ & $(1.11)$ & $(-1.85)$ \\
\hline \multirow[t]{2}{*}{ SIZE } & -0.0000401 & -0.239 & 0.659 & 0.0000173 & -15.80 & 0.000112 & 0.629 & 1.080 & 0.000120 & -14.01 \\
\hline & $(-0.07)$ & $(-0.15)$ & $(0.45)$ & $(0.04)$ & $(-0.82)$ & $(0.19)$ & $(0.43)$ & $(0.85)$ & $(0.35)$ & $(-0.80)$ \\
\hline \multirow[t]{2}{*}{ Constant } & $0.00930^{* * * *}$ & 8.057 & -7.106 & 0.00150 & 81.03 & $0.00931^{* * *}$ & 5.211 & -7.467 & 0.00123 & 62.12 \\
\hline & $(2.73)$ & $(0.80)$ & $(-0.70)$ & $(0.54)$ & $(0.55)$ & $(\mathbf{2 . 8 8})$ & $(0.55)$ & $(-0.80)$ & $(0.47)$ & $(0.44)$ \\
\hline Other variables & $\checkmark$ & $\checkmark$ & $\checkmark$ & $\checkmark$ & $\checkmark$ & $\checkmark$ & $\checkmark$ & $\checkmark$ & $\checkmark$ & $\checkmark$ \\
\hline Time effects & $\checkmark$ & $\checkmark$ & $\checkmark$ & $\checkmark$ & $\checkmark$ & $\checkmark$ & $\checkmark$ & $\checkmark$ & $\checkmark$ & $\checkmark$ \\
\hline $\mathrm{N}$ & 2481 & 1744 & 1719 & 2123 & 2132 & 2481 & 1744 & 1719 & 2123 & 2132 \\
\hline $\mathrm{N}$ & 421 & 390 & 387 & 408 & 410 & 421 & 390 & 387 & 408 & 410 \\
\hline $\mathrm{R} 2$ & 0.463 & 0.0812 & 0.108 & 0.154 & 0.0572 & 0.465 & 0.0841 & 0.110 & 0.153 & 0.0596 \\
\hline $\begin{array}{l}\text { Marginal effect } \\
\text { z-statistic }\end{array}$ & & & & & & & & & & \\
\hline
\end{tabular}

(Table 4 continued on the next page) 
Table 4 continued

Very large banks $(\mathrm{TA} \geq \$ 50 \mathrm{~B})$

\begin{tabular}{|c|c|c|c|c|c|c|c|c|c|c|}
\hline & \multicolumn{5}{|c|}{ Intrastate diversification } & \multicolumn{5}{|c|}{ Interstate diversification } \\
\hline & ROA & RaROA & RaROE & SdROA & $\mathrm{Z}$ & ROA & RaROA & RaROE & SdROA & $\mathrm{Z}$ \\
\hline \multirow[t]{2}{*}{ GEODIV } & -0.00591 & 42.87 & $137.4^{* * * *}$ & -0.0117 & 780.4 & 0.0289 & 75.11 & $187.7^{* * *}$ & -0.00924 & 986.0 \\
\hline & $(-0.65)$ & $(0.93)$ & $(3.54)$ & $(-0.95)$ & $(1.57)$ & $(1.31)$ & (1.68) & $(2.97)$ & $(-0.73)$ & (1.37) \\
\hline \multirow[t]{2}{*}{ GEODIV $^{2}$} & 0.0135 & -44.07 & $-98.08^{* * *}$ & $0.0183^{*}$ & $-796.3^{*}$ & -0.0255 & -59.26 & $-152.0^{* * * *}$ & 0.0111 & -924.1 \\
\hline & $(1.07)$ & $(-1.09)$ & $(-2.60)$ & (1.73) & $(-1.73)$ & $(-1.41)$ & $(-1.54)$ & $(-3.00)$ & (1.21) & $(-1.56)$ \\
\hline \multirow[t]{2}{*}{ SIZE } & -0.000917 & 4.052 & 7.045 & -0.000955 & $141.3^{* * *}$ & 0.000102 & 2.286 & $8.243^{*}$ & -0.000283 & $139.0^{* * *}$ \\
\hline & $(-0.55)$ & $(0.90)$ & $(1.37)$ & $(-0.57)$ & (2.15) & $(0.08)$ & $(0.52)$ & (1.79) & $(-0.19)$ & $(2.28)$ \\
\hline \multirow[t]{2}{*}{ Constant } & -0.00282 & -72.96 & -138.9 & 0.0200 & $-2120.4^{*}$ & -0.0143 & -68.87 & -152.8 & 0.0128 & $-1973.2^{*}$ \\
\hline & $(-0.20)$ & $(-0.70)$ & $(-1.40)$ & $(0.86)$ & $(-2.07)$ & $(-1.21)$ & $(-0.78)$ & $(-1.72)$ & $(0.69)$ & $(-2.05)$ \\
\hline Other variables & $\checkmark$ & $\checkmark$ & $\checkmark$ & $\checkmark$ & $\checkmark$ & $\checkmark$ & $\checkmark$ & $\checkmark$ & $\checkmark$ & $\checkmark$ \\
\hline Time effects & $\checkmark$ & $\checkmark$ & $\checkmark$ & $\checkmark$ & $\checkmark$ & $\checkmark$ & $\checkmark$ & $\checkmark$ & $\checkmark$ & $\checkmark$ \\
\hline $\mathrm{N}$ & 143 & 111 & 108 & 126 & 126 & 143 & 111 & 108 & 126 & 126 \\
\hline $\mathrm{n}$ & 23 & 22 & 20 & 23 & 23 & 23 & 22 & 20 & 23 & 23 \\
\hline $\mathrm{R} 2$ & 0.490 & 0.294 & 0.282 & 0.300 & 0.269 & 0.491 & 0.294 & 0.318 & 0.284 & 0.332 \\
\hline Marginal effect & & & -13.11071 & & & & & -12.0903 & & \\
\hline z-statistic & & & -0.44 & & & & & -0.64 & & \\
\hline
\end{tabular}


Table 5 Geographic diversification and disparities in economic conditions within and across states

This table reports the regression results of our baseline model from fixed-effects models using GD1 and GD2 respectively as measure of geographic diversification (GEODIV). Explained variables are ROA, SdROA, RaROA, RaROE and Z. Each measure of geographic diversification is interacted with our measure of economic disparities (SDUNEMP). GD1 measures intrastate diversification and GD2 measures interstate diversification. GD1 is interacted with our measure of economic disparities within state (SdUnempSt) and GD2 is interacted with our measure of interstate economic disparities (SdUnempCtry). Other control: other control variables presented in section 3.5. N: number of observations; n: number of banks; Marginal effect: when significant non-linear effects are captured by our estimations, the marginal effect is calculated as the first derivative of the explained variable with respect to the geographic diversification index computed using the average value of the geographic diversification index and of the economic disparities variable. R2: adjusted R squared. t statistics in parentheses, ${ }^{*} \mathrm{p}<0.1,{ }^{* * *} \mathrm{p}<0.05,{ }^{* * * *} \mathrm{p}<0.01$. All other variables are defined in Table 1.1.

\begin{tabular}{|c|c|c|c|c|c|c|c|c|c|c|}
\hline & \multicolumn{5}{|c|}{ Intrastate diversification } & \multicolumn{5}{|c|}{ Interstate diversification } \\
\hline & ROA & RaROA & RaROE & SdROA & $\mathrm{Z}$ & ROA & RaROA & RaROE & SdROA & $\mathrm{Z}$ \\
\hline \multirow[t]{2}{*}{ GEODIV } & $0.00341^{* * * *}$ & $6.884^{* * *}$ & $6.834^{* * * *}$ & -0.00105 & 60.51 & $0.0128^{* * * *}$ & 5.011 & 7.753 & -0.00248 & -30.63 \\
\hline & (3.18) & $(2.61)$ & $(2.85)$ & $(-1.53)$ & (1.59) & (3.51) & $(0.42)$ & $(0.73)$ & $(-1.16)$ & $(-0.16)$ \\
\hline \multirow[t]{2}{*}{ GEODIV $^{2}$} & $-0.00434^{* * * *}$ & $-8.897^{* *}$ & $-8.584^{* * * *}$ & 0.000957 & -80.98 & $-0.0155^{* *}$ & -2.950 & -22.38 & 0.00438 & 21.01 \\
\hline & $(-3.09)$ & $(-2.43)$ & $(-2.60)$ & $(1.07)$ & $(-1.58)$ & $(-2.42)$ & $(-0.13)$ & $(-1.10)$ & $(1.09)$ & $(0.06)$ \\
\hline \multirow[t]{2}{*}{ SIZE } & -0.000125 & $0.961^{* * * *}$ & $0.729^{* * * *}$ & $-0.000309^{* * * *}$ & $7.632^{*}$ & $-0.000202^{*}$ & $0.834^{* * *}$ & $0.742^{* * * *}$ & $-0.000303^{* * * *}$ & $7.583^{*}$ \\
\hline & $(-1.12)$ & (3.47) & $(2.88)$ & $(-3.13)$ & $(1.75)$ & $(-1.95)$ & (3.19) & (3.06) & $(-3.25)$ & (1.87) \\
\hline \multirow[t]{2}{*}{ GEODIV*SDUNEMP } & $-0.000778^{* * *}$ & $-1.475^{*}$ & $-1.438^{*}$ & -0.0000286 & $-22.00^{* * *}$ & $-0.00898^{* * * *}$ & 1.164 & -0.540 & 0.000593 & 69.66 \\
\hline & $(-2.44)$ & $(-1.77)$ & $(-1.96)$ & $(-0.15)$ & $(-1.97)$ & $(-3.55)$ & $(0.14)$ & $(-0.07)$ & $(0.38)$ & $(0.53)$ \\
\hline \multirow[t]{2}{*}{ GEODIV $2 *$ SDUNEMP } & 0.000252 & $2.268^{*}$ & $2.648^{* * *}$ & 0.0000273 & $33.99^{* * *}$ & $0.00895^{* *}$ & -7.049 & 7.307 & -0.000516 & -114.7 \\
\hline & $(0.59)$ & (1.68) & $(2.32)$ & $(0.11)$ & (1.97) & $(2.04)$ & $(-0.43)$ & $(0.51)$ & $(-0.18)$ & $(-0.50)$ \\
\hline \multirow[t]{2}{*}{ INCOME } & $-0.000870^{*}$ & $-4.827^{* * * *}$ & $-4.881^{* * * *}$ & $0.00198^{* * *}$ & $-73.50^{* * * *}$ & $-0.000889^{*}$ & $-4.926^{* * * *}$ & $-4.904^{* * * *}$ & $0.00199^{* * * *}$ & $-74.02^{* * * *}$ \\
\hline & $(-1.68)$ & $(-5.47)$ & $(-5.82)$ & $(6.48)$ & $(-5.55)$ & $(-1.72)$ & $(-5.60)$ & $(-5.88)$ & $(6.53)$ & $(-5.61)$ \\
\hline \multirow[t]{2}{*}{ FOREIGN } & 0.00130 & -5.772 & -0.301 & $0.00548^{*}$ & -37.46 & 0.000946 & -8.476 & -1.473 & $0.00618^{* *}$ & -66.15 \\
\hline & $(0.34)$ & $(-1.10)$ & $(-0.06)$ & (1.96) & $(-0.72)$ & $(0.25)$ & $(-1.40)$ & $(-0.27)$ & $(2.11)$ & $(-1.20)$ \\
\hline \multirow[t]{2}{*}{ LOAN } & $-0.00181^{* * * *}$ & -0.0430 & 0.0905 & -0.000139 & -3.393 & $-0.00185^{* * * *}$ & -0.162 & -0.0204 & -0.000131 & -4.657 \\
\hline & $(-3.49)$ & $(-0.05)$ & $(0.10)$ & $(-0.44)$ & $(-0.22)$ & $(-3.57)$ & $(-0.17)$ & $(-0.02)$ & $(-0.42)$ & $(-0.31)$ \\
\hline \multirow[t]{2}{*}{ GROWTH } & $0.00730^{* * * *}$ & $2.521^{* * *}$ & $1.951^{*}$ & $-0.00205^{* * * *}$ & $69.17^{\text {***** }}$ & $0.00735^{* * *}$ & $2.522^{* * *}$ & $1.959^{*}$ & $-0.00206^{* * * *}$ & $69.07^{* * * *}$ \\
\hline & (16.35) & $(2.25)$ & (1.89) & $(-8.31)$ & (3.82) & (16.42) & $(2.25)$ & (1.89) & $(-8.34)$ & (3.82) \\
\hline \multirow[t]{2}{*}{ SdUnempSt } & $0.000273^{* * * *}$ & $-0.165^{*}$ & $-0.163^{*}$ & $0.000101^{* * * *}$ & $-2.593^{*}$ & 0.000176 **** & $-0.207^{* *}$ & $-0.165^{* *}$ & $0.000100^{* * * *}$ & $-3.179^{* * *}$ \\
\hline & $(6.58)$ & $(-1.69)$ & $(-1.79)$ & (3.76) & $(-1.79)$ & (4.75) & $(-2.41)$ & $(-2.05)$ & $(4.32)$ & $(-2.41)$ \\
\hline \multirow[t]{2}{*}{ EQUITY } & $0.0347^{* * * *}$ & $17.84^{* * *}$ & -0.892 & $-0.00540^{\text {***** }}$ & $628.6^{* * * *}$ & $0.0345^{* * *}$ & $17.47^{* * *}$ & -0.995 & $-0.00542^{* * * *}$ & $630.0^{* * *}$ \\
\hline & (17.74) & (5.39) & $(-0.30)$ & $(-4.79)$ & (10.98) & (17.57) & $(5.29)$ & $(-0.34)$ & $(-4.82)$ & (11.02) \\
\hline \multirow[t]{2}{*}{ LIQUID_RISK } & $0.00297^{* * * *}$ & -1.250 & -0.671 & 0.00101 **** & $-28.41^{*}$ & $0.00291^{* * * *}$ & -1.373 & -0.640 & $0.00101^{* * * *}$ & $-28.56^{*}$ \\
\hline & (6.07) & $(-1.28)$ & $(-0.73)$ & (3.28) & $(-1.83)$ & (5.97) & $(-1.41)$ & $(-0.70)$ & (3.32) & $(-1.86)$ \\
\hline \multirow{2}{*}{ CREDIT_RISK } & $-0.279^{* * * *}$ & $-204.2^{* * * *}$ & $-189.3^{* * * *}$ & & & $-0.278^{* * * *}$ & $-204.2^{* * * *}$ & $-189.4^{* * * *}$ & & \\
\hline & $(-24.05)$ & $(-16.24)$ & $(-14.95)$ & & & $(-24.00)$ & $(-16.26)$ & $(-14.98)$ & & \\
\hline \multirow[t]{2}{*}{ Constant } & $0.00438^{* * * *}$ & $8.934^{* * *}$ & $9.962^{* * * *}$ & $0.001966^{* * * *}$ & $85.54^{* * *}$ & $0.00476^{* * * *}$ & $9.417^{* * * *}$ & $10.43^{* * * *}$ & $0.00185^{* * *}$ & $87.78^{\text {**** }}$ \\
\hline & (6.90) & $(7.33)$ & (8.65) & $(5.23)$ & $(4.41)$ & $(7.60)$ & (8.15) & $(9.53)$ & (5.15) & $(4.75)$ \\
\hline Other control & $\checkmark$ & $\checkmark$ & $\checkmark$ & $\checkmark$ & $\checkmark$ & $\checkmark$ & $\checkmark$ & $\checkmark$ & $\checkmark$ & $\checkmark$ \\
\hline Time effects & $\checkmark$ & $\checkmark$ & $\checkmark$ & $\checkmark$ & $\checkmark$ & $\checkmark$ & $\checkmark$ & $\checkmark$ & $\checkmark$ & $\checkmark$ \\
\hline $\mathrm{N}$ & 69911 & 50020 & 48271 & 57535 & 57524 & 69911 & 50020 & 48271 & 57535 & 57524 \\
\hline $\mathrm{n}$ & 6272 & 6150 & 6135 & 6215 & 6213 & 6272 & 6150 & 6135 & 6215 & 6213 \\
\hline $\mathrm{R} 2$ & 0.239 & 0.0387 & 0.0353 & 0.0435 & 0.0261 & 0.239 & 0.0386 & 0.0352 & 0.0437 & 0.0261 \\
\hline Marginal effect & .0007037 & 2.63126 & 2.954874 & & 12.67673 & -.0005347 & & & & \\
\hline z-statistic & 1.17 & $1.88 *$ & $2.25 * *$ & & 0.60 & -0.37 & & & & \\
\hline
\end{tabular}


Table 6: Geographic diversification and disparities in economic conditions within and across states: estimations across bank size

This table reports the regression results of our baseline model from fixed-effects models using GD1 and GD2 respectively as measure of geographic diversification (GEODIV) across different sub-sample of bank size (small banks (TA $\leq \$ 1 \mathrm{~B}$ ); large banks ( $\$ 1 \mathrm{~B}<\mathrm{TA}<\$ 50 \mathrm{~B}$ ); very large banks (TA $\geq \$ 50 \mathrm{~B})$. Explained variables are ROA, SdROA, RaROA, RaROE and Z. Each measure of geographic diversification is interacted with our measure of economic disparities (SDUNEMP). GD1 measures intrastate diversification and GD2 measures interstate diversification. GD1 is interacted with our measure of economic disparities within state (SdUnempSt) and GD2 is interacted with our measure of interstate economic disparities (SdUnempCtry). Other variables: other explanatory and control variables presented in section 3.5. N: number of observations; n: number of banks; Marginal effect: Marginal effect: when significant non-linear effects are captured by our estimations, the marginal effect is calculated as the first derivative of the explained variable with respect to the geographic diversification index computed using the average value of the geographic diversification index and of the economic disparities variable. R2: adjusted R squared. t statistics in parentheses, ${ }^{*} \mathrm{p}<0.1,{ }^{* *} \mathrm{p}<0.05,{ }^{* * *} \mathrm{p}<0.01$. All other variables are defined in Table 1.1 .

Small banks $(\mathrm{TA} \leq \$ 1 \mathrm{~B})$

\begin{tabular}{|c|c|c|c|c|c|c|c|c|c|c|}
\hline & \multicolumn{5}{|c|}{ Intrastate diversification } & \multicolumn{5}{|c|}{ Interstate diversification } \\
\hline & ROA & RaROA & RaROE & SdROA & $\mathrm{Z}$ & ROA & RaROA & RaROE & SdROA & $\mathrm{Z}$ \\
\hline GEODIV & $\begin{array}{c}\mathbf{0 . 0 0 3 7 0}^{* * * *} \\
(2.97)\end{array}$ & $\begin{array}{c}7.245^{* * * *} \\
(2.65)\end{array}$ & $\begin{array}{l}\text { 4.671* } \\
(1.79)\end{array}$ & $\begin{array}{c}-0.000769 \\
(-1.05)\end{array}$ & $\begin{array}{l}61.50 \\
(1.44)\end{array}$ & $\begin{array}{c}\mathbf{0 . 0 2 1 2}^{* * * *} \\
(3.11)\end{array}$ & $\begin{array}{l}8.691 \\
(0.46)\end{array}$ & $\begin{array}{l}21.85 \\
(1.24)\end{array}$ & $\begin{array}{c}0.00150 \\
(0.41)\end{array}$ & $\begin{array}{l}317.8 \\
(0.91)\end{array}$ \\
\hline GEODIV $^{2}$ & $\begin{array}{c}-0.00456 \\
(-2.54)\end{array}$ & $\begin{array}{c}-7.578^{* * *} \\
(-2.02)\end{array}$ & $\begin{array}{l}-3.477 \\
(-0.93)\end{array}$ & $\begin{array}{c}-0.0000748 \\
(-0.07)\end{array}$ & $\begin{array}{l}-42.18 \\
(-0.67)\end{array}$ & $\begin{array}{c}-0.0393 \\
(-2.45)\end{array}$ & $\begin{array}{l}-11.86 \\
(-0.29)\end{array}$ & $\begin{array}{l}-38.41 \\
(-0.94)\end{array}$ & $\begin{array}{c}-0.00467 \\
(-0.54)\end{array}$ & $\begin{array}{l}-798.7 \\
(-0.97)\end{array}$ \\
\hline SIZE & $\begin{array}{c}-0.0000589 \\
(-0.47)\end{array}$ & $\begin{array}{c}1.3366^{* * * *} \\
(4.68)\end{array}$ & $\begin{array}{c}1.060^{* * * *} \\
(4.10)\end{array}$ & $\begin{array}{c}-0.000466 \\
(-4.34)\end{array}$ & $\begin{array}{c}15.83^{* * * *} \\
(3.47)\end{array}$ & $\begin{array}{c}-0.000133 \\
(-1.14)\end{array}$ & $\begin{array}{c}1.121^{* * * *} \\
(4.12)\end{array}$ & $\begin{array}{c}0.970^{* * * *} \\
(3.88)\end{array}$ & $\begin{array}{c}-0.000441^{\text {**** }} \\
(-4.41)\end{array}$ & $\begin{array}{c}14.67^{* * * *} \\
(3.39)\end{array}$ \\
\hline GEODIV*SDUNEMP & $\begin{array}{c}-0.000709^{*} \\
(-1.84)\end{array}$ & $\begin{array}{l}-0.563 \\
(-0.68)\end{array}$ & $\begin{array}{l}-0.172 \\
(-0.21)\end{array}$ & $\begin{array}{c}-0.000231 \\
(-1.12)\end{array}$ & $\begin{array}{l}-7.348 \\
(-0.53)\end{array}$ & $\begin{array}{c}-0.0153^{* * * *} \\
(-3.23)\end{array}$ & $\begin{array}{l}-5.585 \\
(-0.41)\end{array}$ & $\begin{array}{l}-17.01 \\
(-1.32)\end{array}$ & $\begin{array}{c}-0.00170 \\
(-0.62)\end{array}$ & $\begin{array}{l}-294.7 \\
(-1.25)\end{array}$ \\
\hline GEODIV $^{2 *}$ SDUNEMP & $\begin{array}{c}0.000205 \\
(0.34)\end{array}$ & $\begin{array}{l}0.582 \\
(0.44)\end{array}$ & $\begin{array}{l}0.175 \\
(0.13)\end{array}$ & $\begin{array}{c}0.000326 \\
(1.05)\end{array}$ & $\begin{array}{l}5.180 \\
(0.22)\end{array}$ & $\begin{array}{c}0.0278^{* * *} \\
(2.48)\end{array}$ & $\begin{array}{l}14.56 \\
(0.48)\end{array}$ & $\begin{array}{l}37.76 \\
(1.26)\end{array}$ & $\begin{array}{c}0.00281 \\
(0.46)\end{array}$ & $\begin{array}{l}810.7 \\
(1.47)\end{array}$ \\
\hline Constant & $\begin{array}{c}0.00402^{* * * *} \\
(6.10)\end{array}$ & $\begin{array}{c}8.2266^{* * * *} \\
(6.61)\end{array}$ & $\begin{array}{c}10.03^{* * * *} \\
(8.59)\end{array}$ & $\begin{array}{c}0.00200^{* * * *} \\
(5.18)\end{array}$ & $\begin{array}{c}\mathbf{7 3 . 1 4}^{* * * * *} \\
(\mathbf{3 . 7 1})\end{array}$ & $\begin{array}{c}0.00447^{* * * *} \\
(6.85)\end{array}$ & $\begin{array}{c}9.130^{* * * *} \\
(7.75)\end{array}$ & $\begin{array}{c}10.69^{* * * *} \\
(9.64)\end{array}$ & $\begin{array}{c}0.00185^{* * * *} \\
(4.95)\end{array}$ & $\begin{array}{c}\text { 83.11 }^{* * * *} \\
(4.40)\end{array}$ \\
\hline Other variables & $\checkmark$ & $\checkmark$ & $\checkmark$ & $\checkmark$ & $\checkmark$ & $\checkmark$ & $\checkmark$ & $\checkmark$ & $\checkmark$ & $\checkmark$ \\
\hline Time effects & $\checkmark$ & $\checkmark$ & $\checkmark$ & $\checkmark$ & $\checkmark$ & $\checkmark$ & $\checkmark$ & $\checkmark$ & $\checkmark$ & $\checkmark$ \\
\hline $\mathrm{N}$ & 67287 & 48165 & 46444 & 55286 & 55266 & 67287 & 48165 & 46444 & 55286 & 55266 \\
\hline $\mathrm{N}$ & 6133 & 5948 & 5937 & 6018 & 6017 & 6133 & 5948 & 5937 & 6018 & 6017 \\
\hline $\mathrm{R} 2$ & 0.237 & 0.0379 & 0.0337 & 0.0426 & 0.0260 & 0.236 & 0.0377 & 0.0338 & 0.0425 & 0.0261 \\
\hline $\begin{array}{l}\text { Marginal effect } \\
\text { z-statistic }\end{array}$ & $\begin{array}{c}.0011553 \\
1.67 *\end{array}$ & $\begin{array}{c}4.393851 \\
2.87 * * *\end{array}$ & & & & $\begin{array}{c}-.0014434 \\
-0.58\end{array}$ & & & & \\
\hline
\end{tabular}

(Table 6 continued on the next page) 
Table 6 continued

Large banks ( $\$ 1 \mathrm{~B}<\mathrm{TA}<\$ 50 \mathrm{~B})$

\begin{tabular}{|c|c|c|c|c|c|c|c|c|c|c|}
\hline & \multicolumn{5}{|c|}{ Intrastate diversification } & \multicolumn{5}{|c|}{ Interstate diversification } \\
\hline & ROA & RaROA & RaROE & SdROA & $\mathrm{Z}$ & ROA & RaROA & RaROE & SdROA & $\mathrm{Z}$ \\
\hline \multirow[t]{2}{*}{ GEODIV } & 0.00511 & 11.69 & 12.53 & $-0.00692^{* *}$ & 113.0 & -0.00669 & -8.298 & $-42.56^{*}$ & -0.00536 & -114.3 \\
\hline & $(1.18)$ & $(0.77)$ & $(0.92)$ & $(-2.24)$ & $(0.57)$ & $(-1.05)$ & $(-0.29)$ & $(-1.68)$ & $(-1.04)$ & $(-0.26)$ \\
\hline \multirow[t]{2}{*}{ GEODIV $^{2}$} & $-0.00788^{*}$ & -18.20 & -17.66 & $0.00938^{* * * *}$ & -207.5 & 0.00392 & 16.72 & 59.15 & 0.0101 & 415.8 \\
\hline & $(-1.79)$ & $(-1.08)$ & $(-1.25)$ & (2.69) & $(-1.01)$ & $(0.41)$ & $(0.36)$ & $(1.39)$ & (1.18) & $(0.54)$ \\
\hline \multirow[t]{2}{*}{ SIZE } & $-0.00104^{* *}$ & -0.00770 & 0.839 & 0.00000430 & -14.07 & $-0.000804^{* *}$ & 0.516 & 1.069 & 0.000110 & -15.82 \\
\hline & $(-2.58)$ & $(-0.00)$ & $(0.59)$ & $(0.01)$ & $(-0.72)$ & $(-1.97)$ & $(0.36)$ & $(0.85)$ & $(0.32)$ & $(-0.90)$ \\
\hline \multirow[t]{2}{*}{ GEODIV*SDUNEMP } & $-0.00272^{*}$ & $-10.89^{*}$ & -4.950 & $0.00383^{\text {*** }}$ & $-137.9^{*}$ & 0.000148 & 7.898 & $35.31^{* * *}$ & 0.00358 & 223.6 \\
\hline & $(-1.72)$ & $(-1.88)$ & $(-0.99)$ & $(\mathbf{2 . 6 3 )}$ & $(-1.68)$ & $(0.04)$ & $(0.41)$ & $(2.07)$ & $(1.01)$ & $(0.74)$ \\
\hline \multirow[t]{2}{*}{ GEODIV²*SDUNEMP } & $0.00279^{*}$ & $14.54^{* * *}$ & $8.971^{*}$ & $-0.00418^{* * * *}$ & $161.7^{* * *}$ & -0.00145 & -22.70 & $-50.65^{*}$ & -0.00565 & -547.6 \\
\hline & $(\mathbf{1 . 8 5})$ & $(\mathbf{2 . 4 2})$ & (1.81) & $(-3.08)$ & $(2.20)$ & $(-0.23)$ & $(-0.70)$ & $(-1.71)$ & $(-0.93)$ & $(-1.06)$ \\
\hline \multirow[t]{2}{*}{ Constant } & $0.0106^{* * * *}$ & 3.358 & -9.234 & 0.00315 & 4.101 & $0.0105^{* * *}$ & 0.706 & -11.14 & 0.00252 & -2.854 \\
\hline & (3.15) & $(0.32)$ & $(-0.88)$ & $(1.10)$ & $(0.03)$ & (3.29) & $(0.07)$ & $(-1.15)$ & $(0.93)$ & $(-0.02)$ \\
\hline Other variables & $\checkmark$ & $\checkmark$ & $\checkmark$ & $\checkmark$ & $\checkmark$ & $\checkmark$ & $\checkmark$ & $\checkmark$ & $\checkmark$ & $\checkmark$ \\
\hline Time effects & $\checkmark$ & $\checkmark$ & $\checkmark$ & $\checkmark$ & $\checkmark$ & $\checkmark$ & $\checkmark$ & $\checkmark$ & $\checkmark$ & $\checkmark$ \\
\hline $\mathrm{N}$ & 2481 & 1744 & 1719 & 2123 & 2132 & 2481 & 1744 & 1719 & 2123 & 2132 \\
\hline $\mathrm{N}$ & 421 & 390 & 387 & 408 & 410 & 421 & 390 & 387 & 408 & 410 \\
\hline R2 & 0.457 & 0.0907 & 0.117 & 0.163 & 0.0595 & 0.459 & 0.0839 & 0.113 & 0.153 & 0.0603 \\
\hline Marginal effect & -.0027052 & -.9260718 & & .0018823 & -57.5614 & \multirow{2}{*}{\multicolumn{5}{|c|}{$\begin{array}{c}2.067765 \\
0.40\end{array}$}} \\
\hline z-statistic & -1.53 & -0.16 & & 1.58 & -1.00 & & & & & \\
\hline \multicolumn{11}{|c|}{ Very large banks $(\mathrm{TA} \geq \$ 50 \mathrm{~B})$} \\
\hline & \multicolumn{5}{|c|}{ Intrastate diversification } & \multicolumn{5}{|c|}{ Interstate diversification } \\
\hline & ROA & RaROA & RaROE & SdROA & $\mathrm{Z}$ & ROA & RaROA & RaROE & SdROA & $\mathrm{Z}$ \\
\hline \multirow[t]{2}{*}{ GEODIV } & -0.00864 & 38.26 & $131.4^{*}$ & $-0.0244^{*}$ & 983.0 & 0.0592 & 137.8 & $469.6^{* *}$ & $-0.155^{* * *}$ & 1172.9 \\
\hline & $(-0.84)$ & $(0.96)$ & (1.89) & $(-1.82)$ & $(1.44)$ & $(1.50)$ & $(0.88)$ & $(2.57)$ & $(-3.86)$ & $(0.72)$ \\
\hline \multirow[t]{2}{*}{ GEODIV $^{2}$} & 0.0111 & -39.96 & -100.0 & $0.0298^{* *}$ & -1037.3 & $-\mathbf{0 . 0 7 0 7}$ & -83.06 & $-385.5^{* *}$ & $0.136^{* * *}$ & -480.6 \\
\hline & $(0.79)$ & $(-1.01)$ & $(-1.57)$ & $(2.18)$ & $(-1.55)$ & $(-1.84)$ & $(-0.57)$ & $(-2.29)$ & (3.57) & $(-0.30)$ \\
\hline \multirow[t]{2}{*}{ SIZE } & -0.000567 & 4.051 & 7.580 & -0.00102 & $146.1^{*}$ & 0.000440 & 3.031 & $12.03^{* * *}$ & $-0.00239 \%$ & $139.9^{* * *}$ \\
\hline & $(-0.35)$ & $(0.77)$ & $(1.25)$ & $(-0.57)$ & $(2.07)$ & $(0.41)$ & $(0.55)$ & $(2.49)$ & $(-1.81)$ & $(2.13)$ \\
\hline \multirow[t]{2}{*}{ GEODIV*SDUNEMP } & $0.0143^{* * *}$ & 4.051 & 11.23 & 0.0108 & -118.8 & -0.0109 & -58.03 & $-200.5^{*}$ & $0.103^{* * * *}$ & -495.6 \\
\hline & $(2.42)$ & $(0.10)$ & $(0.24)$ & $(1.41)$ & $(-0.39)$ & $(-0.68)$ & $(-0.49)$ & $(-1.94)$ & (3.84) & $(-0.55)$ \\
\hline \multirow[t]{2}{*}{ GEODIV2*SDUNEMP } & $-0.00959^{*}$ & -3.482 & -7.070 & -0.00939 & 127.0 & 0.0225 & 28.00 & 169.5 & $-0.0891^{* * * *}$ & 4.347 \\
\hline & $(-2.04)$ & $(-0.11)$ & $(-0.18)$ & $(-1.43)$ & $(0.49)$ & $(1.22)$ & $(0.25)$ & $(1.72)$ & $(-3.60)$ & $(0.00)$ \\
\hline \multirow[t]{2}{*}{ Constant } & 0.00309 & -71.35 & -139.0 & 0.0245 & $-2178.6^{* *}$ & $-0.0167^{*}$ & -69.77 & -154.8 & 0.0195 & $-1895.1^{*}$ \\
\hline & $(0.26)$ & $(-0.68)$ & $(-1.36)$ & $(1.10)$ & $(-2.11)$ & $(-1.93)$ & $(-0.74)$ & $(-1.54)$ & $(1.14)$ & $(-1.81)$ \\
\hline Other variables & $\checkmark$ & $\checkmark$ & $\checkmark$ & $\checkmark$ & $\checkmark$ & $\checkmark$ & $\checkmark$ & $\checkmark$ & $\checkmark$ & $\checkmark$ \\
\hline Time effects & $\checkmark$ & $\checkmark$ & $\checkmark$ & $\checkmark$ & $\checkmark$ & $\checkmark$ & $\checkmark$ & $\checkmark$ & $\checkmark$ & $\checkmark$ \\
\hline $\mathrm{N}$ & 143 & 111 & 108 & 126 & 126 & 143 & 111 & 108 & 126 & 126 \\
\hline $\mathrm{n}$ & 23 & 22 & 20 & 23 & 23 & 23 & 22 & 20 & 23 & 23 \\
\hline $\mathrm{R} 2$ & 0.509 & 0.276 & 0.267 & 0.292 & 0.256 & 0.510 & 0.305 & 0.351 & 0.423 & 0.368 \\
\hline Marginal effect & .0084829 & & & .0166175 & & & & -4.843855 & .0037574 & \\
\hline z-statistic & 0.63 & & & $2.07 * *$ & & & & -0.26 & 0.98 & \\
\hline
\end{tabular}

